\title{
WHEN BULLETS PENETRATE BULLET-PROOF VESTS: CONFORMITY OF THE BULLET-PROOF MATERIAL TO THE CONTRACT OF SALE AND CONCURRENT REMEDIES (A NOTE ON THE JUDGMENT OF THE MULTI-MEMBER COURT OF FIRST INSTANCE OF ATHENS 4505/2009)
}

\author{
Dionysios P. Flambouras ${ }^{*}$
}

\section{INTRODUCTION}

1. The Vienna Convention of 1980 for the International Sale of Goods (the "Vienna Convention" or "CISG") was entered into force in Greece on 1.2.1999 by virtue of law no. 2532/1997 (Gov. Gazette A 227/11.11.1997) and has since then been applied and interpreted by fourteen Greek judgments. ${ }^{1}$ The judgment of the Multi-Member Court of First Instance of Athens 4505/2009 ("Judgment 4505/2009") is, if not the most important, one of the most important cases. ${ }^{2}$ Its importance is based not only on the CISG legal issues on which it expressed an opinion, but also on the particularities (and complexities) of its facts (its original text exceeds 100 pages and is still unpublished in Greece). On this basis the author believes that the full understanding of the legal issues of Judgment 4505/2009 requires systematic and, to the extent possible, detailed presentation of its complicated facts. It is

* $\quad$ Part-Time Lecturer (Presidential Decree 407/1980) in Civil Law in the University of Athens (Department of Economics). Senior Associate of M. \& P. Bernitsas Law Offices, Athens, Greece (Banking \& Finance Department) (www.bernitsaslawoffices.gr). Attorney-at-Law (Athens Bar), Solicitor in England \& Wales. J.D. (Athens), LL.M. (Bristol), M. St. (Oxford, Worcester College), Dr. iur. in Civil Law (Athens). For comments: dflamb@econ.uoa.gr. This note is dedicated to the memory of Professor Albert H. Kritzer having been a teacher and a friend to the author for the last ten years. This note has been prepared following a number of discussions with Professor Kritzer on Judgment 4505/2009 and the author had the privilege to have Professor Kritzer's valuable views on an earlier, but sadly not on the final, draft of this work. A shorter version of this note in Greek is part of a commentary-monograph prepared by the author under the title "The Law of the International Sale of Goods-A contribution to the interpretation of the UN convention on the International Sale of Goods, Incoterms 2000 and Law 2251/1994," published in October 2010 by NOMIKI VIVLIOTHIKI publishers.

1. See Dionysios Flambouras, Case Law of Greek Courts for the Vienna Convention (1980) for International Sale of Goods, 2 Nordic J. COM. L. (2009), available at http://www.njcl.utu.fi/2_2009/ flambouras_dionysios.pdf.

2. Polimeles Protodikio Athinon [Multi-Member Court of First Instance of Athens] Greece, 2009 [hereinafter Judgment 4505/2009], available at http://cisgw3.law.pace.edu/cases/094505gr.html. 
noted that Judgment 4505/2009 also deals with important legal issues relating to international jurisdiction ${ }^{3}$ and Greek domestic civil law. However, this note will only concentrate, with few exceptions, on legal issues relating to the CISG.

\section{FACTS ${ }^{4}$}

\section{A. Pre-Contractual Stage}

2. A Greek authority (the "Authority"), through a Greek Ministry (the "Ministry") and in cooperation with a company owned by the Greek State who manufactured arms/weapons (the "State Weapon Co."), wanted to acquire bullet-proof vests for its personnel. The State Weapon Co. undertook to manufacture and supply the vests to the Authority. Prior to the conclusion of the relevant manufacture and supply agreements, the State Weapon Co. launched an international lowest-bidder tender for the procurement of bulletproof material to be used in the manufacture of the bullet-proof vests and sent invitations to various manufacturers (including " $X$ " Co., a Dutch corporation) (the "Dutch Supplier"); the invitation included evaluation criteria for light equipment of NIJ IIIa type set out in detail in the text of Judgment 4505/2009. Based on the invitation of the State Weapon Co., "Y" Co., a Greek company and a direct subsidiary of the State Weapon Co. (the "State Weapon Co. Subsidiary"), offered to manufacture bullet-proof vests providing a level of protection corresponding to the specifications set out by the National Institute of the USA (NIJ) 0101.03, level IIA, with the understanding that the vests would be tested in an official laboratory in accordance with the methods of NIJ. On 14.2.2000, the Dutch Supplier submitted its financial tender to the State Weapon Co. for a new experimental light bullet-proof material under the name "D" (the "Bullet-Proof Material"); the financial tender of the Dutch Supplier, inter alia, (i) set out specific temporary specifications for the BulletProof Material; (ii) pointed out that the Bullet-Proof Material was a new product in the market and did not exist for enough time in order to have real experience data; (iii) included a warranty by the Dutch Supplier that the

3. For English translation of the parts of Judgment 4505/2009 related to jurisdictional matters, see Dionysios Flambouras, Editorial Remarks to Judgment 4505/2009, §§ 2.1.1-2.1.5, available at http:// cisgw3.law.pace.edu/cases/094505gr.html.

4. For full presentation of facts and translation of the relevant legal parts of Judgment 4505/2009, see Dionysios Flambouras, Editorial Remarks to Judgment 4505/2009, §§ 1.1-1.11, at http://cisgw3 .law.pace.edu/cases $/ 094505 \mathrm{gr} . h \mathrm{tml}$. 
Bullet-Proof Material would maintain compliance with the specifications set out in the technical manual issued for this type of material, for a "life" expectancy of ten years from the date of delivery, provided that the terms set out in the technical manual were complied with; and (iv) offered an amount of $5 \mathrm{DM}$ per kg of Bullet-Proof Material after the end of the period of use of the bullet-proof vests. In order to select the supplier of the bullet-proof material ballistic tests were conducted in the Institute of G. University in the U.K. in November 2000. The tests were performed on prospective unprocessed bullet-proof materials (including the Bullet-Proof Material) and not on vests manufactured from such materials. Based on the results of the tests the State Weapon Co. and the State Weapon Subsidiary Co. considered the tender of the Dutch Supplier as the most advantageous and decided to purchase from the latter the unprocessed Bullet-Proof Material, which would be used by the State Weapon Subsidiary Co. in order to manufacture bulletproof vests for the Authority.

\section{B. Contract for the Supply of Bullet-Proof Vests Between the State Weapon Co. and the Ministry (Bullet-Proof Vests Supply Contract)}

3. On 21.6.2001 an agreement (no. 16A/2001) was concluded (the "Bullet-Proof Vests Supply Contract") under which the State Weapon Co. agreed to supply to the Ministry and the Authority 10,020 bullet-proof vests with protection level IIA (the "Bullet-Proof Vests") and 2,000 bullet-proof slabs with protection level III. The Bullet-Proof Vests Supply Contract provided, inter alia, the following: (i) as regards the Bullet-Proof Material, the Bullet-Proof Vests would originate from the Dutch Supplier; however, the production and the control of the final product (i.e. the Bullet-Proof Vests) would be performed by the State Weapon Co.; (ii) the State Weapon Co. would have the exclusive responsibility for the qualitative examination of the Bullet-Proof Material (and any relevant technical improvementsmodifications) to be performed at its premises; (iii) the contractual material would be accompanied, upon delivery to the Ministry's committee for the final take over, with compliance certificates issued by the Dutch Supplier and the State Weapon Co. which would cover the inland part, as well as the BulletProof Vest as a final product; (iv) following production of the Bullet-Proof Vests by the State Weapon Co. and delivery of each instalment and receipt of a relevant written notice by the Ministry, the Ministry would proceed with a qualitative examination of the end product and qualitative receipt of the product; (v) the Greek Weapon Co. warranted the good "behaviour" of the Bullet-Proof Material for ten years; (vi) within twenty days from the 
verification of a defect, the Ministry would provide a written notification to the State Weapon Co., in connection with any defective part, which would be covered by the contractual warranty and would return such defective part to the premises of the State Weapon Co., accompanied by detailed relevant minutes explaining the reasons for which repair or replacement is necessary and State Weapon Co. would proceed with any necessary repair as soon as possible at its own expenses; (vii) in the event that, within the warranty period, a defective part of the same material appears for a percentage exceeding $10 \%$ of the goods received, such defect would be classified as "systematic" and the State Weapon Co. would be obliged to replace the defective part in all material, free of charge for the Ministry; (viii) the technical characteristics-specifications for the Bullet-Proof Vests and the process in order to effect macroscopic and operative control in connection with the high standard of the Bullet-Proof Vests; (ix) that the State Weapon Co. would manufacture $100 \%$ Bullet-Proof Vests and such manufacturing would be performed at its premises or at the premises of its Greek subcontractors; and (x) that the State Weapon Co. would acquire Bullet-Proof Material of $1.69 \mathrm{~m}$ width.

\section{Contract for Sale of Bullet-Proof Material Between the Dutch Supplier and State Weapon Subsidiary Co. (Bullet-Proof Material Sale Contract)}

4. On 4.7.2001 an agreement was concluded (the "Bullet-Proof Material Sale Contract") under which the Dutch Supplier (the "Seller") agreed to sell to the State Weapon Subsidiary Co. (the "Buyer") Bullet-Proof Material (i.e. "D") under the following terms and conditions: (i) the Seller would sell to the Buyer 155,000 linear meters $(\mathrm{lm})$ of Bullet-Proof Material $160 \mathrm{~cm}$ wide for a total price of $€ 2,515,464$ (Cl. 1); (ii) the Bullet-Proof Material would be delivered to the Buyer in instalments as follows: 1st instalment 15,000 lm by January 2002, 2nd instalment 20,000 $\mathrm{lm}$ by February 2002, 3rd instalment 20,000 $\mathrm{lm}$ by March 2002, 4th instalment 25,000 lm by April 2002, 5th instalment 30,000 $\mathrm{lm}$ by May 2002, 6th instalment 30,000 $\mathrm{lm}$ by June 2002 and 7th instalment 15,000 lm by July 2002 (Cl. 2.1); (iii) the Department of Purchase and the Department of Qualitative Examination of the Buyer would take over each instalment and would perform initial examination of the BulletProof Material; during the process for the taking over and examination of the Bullet-Proof Material the Seller or its authorised representative would be present in order to execute a relevant protocol (Cl. 2.3); (iv) the Seller would accompany each instalment of Bullet-Proof Material with a quality compliance certificate $(\mathrm{Cl} .2 .6)$; (v) payment of the purchase price by the 
Buyer would be effected as follows: $40 \%$ of the total purchase price (i.e. $€ 1,006,185.60)$ would be paid in advance by 15 July 2001 against a bank guarantee while the remaining balance (i.e. $€ 1,509,278.40$ ) would be paid in instalments within thirty days upon receipt of an invoice for each delivery instalment (Cl. 3.2); (vi) if the Bullet-Proof Material would not fully comply with the specifications, the Buyer would be entitled to reject it in full or in part (Cl. 4.1) and the Seller would be obliged to replace the rejected quantity with a respective quantity of Bullet-Proof Material that would comply with the specifications within 30 days following notification of the relevant report prepared by the Department of Qualitative Examination of the Buyer; (vii) the Seller warranted that the Bullet-Proof Material was free of any legal defect and of any apparent or hidden defect for a period of one year starting from the date of delivery (Cl. 7.3); (viii) the Bullet-Proof Material Sale Contract provided that it would prevail over any other relevant document (in the absence of manifest error) and that any amendment in its terms would only be agreed in writing excluding any other manner for such amendment (Cl. 9.3).

D. Contract for the Manufacturing of Bullet-Proof Vests Between the State Weapon Subsidiary Co. and the State Weapon Co. [Bullet-Proof Vests Manufacturing Contract]

5. On 19.7.2001 an agreement was concluded (the "Bullet-Proof Vests Manufacturing Contract") under which the State Weapon Subsidiary Co. (being Buyer under the Bullet-Proof Material Sale Contract) ${ }^{5}$ undertook to manufacture and deliver to the State Weapon Co. the Bullet-Proof Vests and 2,000 bullet-proof slabs with protection level III (as set out in Schedule A to the Bullet-Proof Vests Supply Contract) for a total price of $€ 5,203,154.37$ (plus VAT). The Bullet-Proof Vests Supply Contract ${ }^{6}$ was attached as schedule to and constituted an integral part to the Bullet-Proof Vests Manufacturing Contract. The State Weapon Subsidiary Co. declared that it was fully aware of the terms and schedules A-H of the Bullet-Proof Vests Supply Contract and the obligations that the State Weapon Co. had undertaken towards the Ministry. It was further agreed that if the State Weapon Co. or the Ministry would discover, until final take over, any defect or damage that could be remedied in the Bullet-Proof Vests manufactured by the State Weapon Subsidiary Co., they would be entitled to demand from the State Weapon

5. See supra $₫ 3$.

6. See supra $\llbracket 2$. 
Subsidiary Co. to remedy such defect or damage at its own expenses within the time frame set out in the Bullet-Proof Vests Supply Contract.

\section{E. Partial Performance of the Bullet-Proof Material Sale Contract-Non- Payment of Part of the Purchase Price}

6. In the context of the Bullet-Proof Material Sale Contract, the Buyer [i.e. State Weapon Subsidiary Co.] paid in advance to the Seller [i.e. Dutch Supplier] on 12.6.2001 the amount of $€ 1,006,185.60$ ( $40 \%$ of the total price). During the period between 11.1.2002 and 19.8.2002, the Seller delivered to the Buyer in instalments (ten "shipments") 125,129 lm of Bullet-Proof Material. Each instalment delivered was accompanied by an invoice and a compliance certificate; in each compliance certificate: (i) it was confirmed that the Bullet-Proof Material complied with the applicable manufacturing specifications for the product level which had been examined, pursuant to the internal examination procedures adopted by the Seller; and (ii) specific reference was made to the fact the Buyer should examine the fitness of the level (i.e. of the Bullet-Proof Material) for the actual application and (the Buyer) was not released of its obligation to conduct the usual examination for the Bullet-Proof Material that it was taking over. Every instalment (shipment) went through qualitative and quantitative examination by the Department of Purchase and the Department of Qualitative Examination of the Buyer and the Buyer never rejected any quantity of delivered Bullet-Proof Material. The Buyer timely paid, with few minor delays, the price for the first six instalments (shipments) of Bullet-Proof Material (approximately 125,000 lm for $€ 779,650$ ). However, the Buyer did not pay within the agreed time frame (and even though an additional 30-day extension period was granted) the price for the subsequent four instalments ("shipments") that it had already taken over corresponding to 5,461 $\mathrm{lm}$ (value of $€ 53,175.129$ ), 25,000 $\mathrm{lm}$ (value of $€ 243,432$ ), 24,600 $\mathrm{lm}$ (value of €237,537.09) and 24,600 $\mathrm{lm}$ (value of $€ 146,059.20)$.

\section{F. Failure at 20.9.2002 Ballistic Test: Penetration of a Bullet-Proof Vest}

7. Correspondence was exchanged between the Seller and the Buyer and a meeting was held in Athens on 25.9.2002 where the Buyer's representatives assured the Seller that it would discharge the unsettled invoices by the end of September 2002. Furthermore, the Seller was informed that on 20.9.2002, the Visiting Team for Qualitative Examination, which had been established for 
the monitoring of the Bullet-Proof Vests Supply Contract, ${ }^{7}$ proceeded, at the premises of the ballistic station of the company "P" owned by the Greek State (the "Greek Ballistic Station"), with ballistic examination of a Bullet-Proof Vest manufactured by the State Weapon Subsidiary Co. [under the BulletProof Vests Manufacturing Contract $\left.{ }^{8}\right]$ from sample Bullet-Proof Material originating from the 5th instalment ("shipment") of Bullet-Proof Material (sold from the Dutch Supplier (Seller) to the State Weapon Subsidiary Co. (Buyer) under the Bullet-Proof Material Sale Contract). ${ }^{9}$ The ballistic examinations included shots with sub-machine-gun of $9 \mathrm{~mm}$ and MAGNUM pistol $44 \mathrm{~mm}$. The following ammunition was used: 9mmX 19 Full Metal jacket Lot 304-IVI-79; this was not the ammunition set out in annex B of the Bullet-Proof Vests Supply Contract ${ }^{10}$ which should be used, under the BulletProof Vests Supply Contract, for the operating examination of the sample Bullet-Proof Vest. In particular, during the ballistic examinations it was found that in the 5th shot (out of 6 shots) with the MP5 sub-machine-gun, from a five meter distance and with a speed of $426 / 15 \mathrm{~m} / \mathrm{s}$, the Bullet-Proof Vest was penetrated. In particular the Bullet-Proof Vest that was examined at the ballistic tests was of an external type with a zip on the front side and each of two front breastplates was covering the other front breastplate for approximately $10 \mathrm{~cm}$; it was further noted that the "failure" occurred at the imaginary line of the breastplates overlapping of the specific Bullet-Proof Vest.

On 8.10.2002 and on 9.10.2002 the State Weapon Co. informed the Seller (the Dutch Supplier) that it would suspend payments for the outstanding price owed for delivered Bullet-Proof Material (under the Bullet-Proof Material Sale Contract) ${ }^{11}$ since the Ministry had also suspended payments owed under the Bullet-Proof Vests Supply Contract ${ }^{12}$ due to failure in the ballistic tests of 20.9.2002 and until a failure analysis is completed. Furthermore the Ministry demanded (under the Bullet-Proof Vests Supply Contract) that the State Weapon Co. replace the Bullet-Proof Material in the Bullet-Proof Vests that had already been delivered (and the ones that would be delivered in the future)

7. See supra $\llbracket 3$.

8. See supra 44

9. See supra 94.

10. See supra 93.

11. See supra 94.

12. See supra $₫ 3$. 
with alternative bullet-proof material (as set out in the Failure Analysis report $\left.^{13}\right)$.

\section{G. 30.10.2002 and 1.11.2002 Ballistic Tests-Failure Analysis}

8. Due to the penetration of the Bullet-Proof Vest at the ballistic test of 20.9.2002 it was unanimously resolved by the Visiting Team for Qualitative Examination of the State Weapon Co. and the representatives of the Authority that the State Weapon Co. should proceed with a Failure Analysis of the incident in order to establish whether the incident was accidental or constituted systematic failure. On 30.10.2002, ballistic tests took place in the Greek Ballistic Station where model frames of $40 \mathrm{cmX} 40 \mathrm{~cm}$ were tested for which samples of Bullet-Proof Material were used originating from the same lot of production and one sample originated from the roll of Bullet-Proof Material that was used in order to manufacture the Bullet-Proof Vest that was penetrated in the ballistic test of 20.9.2002. 80 shots were performed with an MP5 gun, from five meters distance and with the speed of $426+/-25 \mathrm{~m} / \mathrm{s}$ in the presence of representatives of the Seller (Dutch Supplier); these shots did not show any unusual behavior of the Bullet-Proof Material in order to render it suspicious for the causing of failure.

Having evaluated the ballistic tests with the Bullet-Proof Material, the failure analysis dated 10.3.2003 (the "Failure Analysis") concluded that from the results of the ballistic tests, one could not attribute the failure of the Bullet-Proof Vest to a systematic failure of the Bullet-Proof Material from which the Bullet-Proof Vest was manufactured. Since in the ballistic tests of 20.9.2002 the failure occurred at the imaginary line of overlapping of the two chest covers of the specific Bullet-Proof Vest, in the ballistic tests of 30.10.2002 the design of the Bullet-Proof Vest was tested by using an equation model in order to check the effect of the design factor. In particular five shots took place on 1.11.2002 in the Greek Ballistic Station at the equation model for the relevant type of Bullet-Proof Vest and the circumstances in which the failure appeared during the ballistic tests of 20.9.2002; these five shots were performed with the MP5 gun, from five meters at a speed of $426+/-15 \mathrm{~m} / \mathrm{s}$ and one penetration appeared without deformation of the bullet, whereas in the other four shots the bullets were deformed. Having evaluated the above ballistic tests over the equation model for the design of the Bullet-Proof Vest, the Failure Analysis concluded, inter 
alia, the following: (i) that the penetration was a strong indication of bad operation (failure) of the Bullet-Proof Material in the specific design of the Bullet-Proof Vest; (ii) that the tendency of the fiber (to be penetrated) in the event of unidirectional structure of the Bullet-Proof Material when the chests are overlapping, was clearly larger in comparison with the case of homogeneous substratum; and (iii) that the resistance of the chest to penetration was relative to the resistance of the fibers, which in the event of non-homogenous substratum was more distressed and as a result an increased possibility of penetration appeared. It was further noted that at those shots, the following ammunition was used, i.e., 9X9mm NATO of the Canadian company IVI (LOT 304-I.V.I.-79), with a nominal mass of bullet 7.5g. (115 grains) and not the ammunition provided by annex B (part of the operating test of the Bullet-Proof Vests) of the Bullet-Proof Vests Supply Contract. ${ }^{14}$ In addition, during the test there were high speeds V2 (average of $434 \mathrm{~m} / \mathrm{s}$ ), in comparison to the requirements of the specification set out in the Bullet-Proof Vests Supply Contract $(426 \mathrm{~m} / \mathrm{s})$, while four out of those counted during test speeds V2 (out of 18), were exceeding the limit set by the above specification $(441 \mathrm{~m} / \mathrm{s})$. At the end, the Failure Analysis suggested, as best possible operation of bullet-proof material in fabric form, the aramidic material (Kevlar, Twaron) which is also available in fabric form in comparison to the structure of the Bullet-Proof Material; this suggestion was due to the fact that in tests conducted on 6.12.2002 at the Greek Ballistic Station with an MP5 gun, from a distance of five meters and speed of $426+/-\mathrm{m} / \mathrm{s}$, with ten shots at an equation sample of $40 \mathrm{cmX} 40 \mathrm{~cm}$ of Twaron CT 709wrt (29 Layers) which was placed on top of an equation sample of $40 \mathrm{cmX} 20 \mathrm{~cm}$ of BulletProof Material, it appeared that there was no penetration and that the bullets were deformed regularly and symmetrically, which constituted a strong indication that the causes which resulted in failure did not exist anymore.

\section{H. Exchange of Correspondence Between Seller and Buyer-Seller's and} Buyer's Arguments

9. Correspondence was exchanged between the Seller (Dutch Supplier) and the Buyer (State Weapon Subsidiary Co.) from which it is concluded that the Buyer did not discharge the three outstanding invoices of aggregate amount of $€ 438,771.58$, that the Seller offered to assist the Buyer and suggest a solution to the design problem of the bullet-proof vest and asked the Buyer

14. See supra $\llbracket 3$. 
to send to it a sample vest of the ones used in the ballistic test of 20.9.2002 and that the Seller requested a third company to manufacture on behalf of the Buyer the specific equation sample and following relevant tests it had found alternative solutions for the penetration problem faced by the Bullet-Proof Vest that the Buyer [State Weapon Subsidiary Co.] had manufactured for the Authority having used Bullet-Proof Material. The Seller demanded discharge of the outstanding amount and asked the Buyer to take delivery of the remaining quantity $(29,871 \mathrm{~lm})$ of the Bullet-Proof Material which had not yet been delivered to the Buyer under the Bullet-Proof Material Sale Contract. The Buyer informed the Seller that the Failure Analysis ${ }^{15}$ showed that there was a problem arising from the combination of the Bullet-Proof Material used for the specific type of Bullet-Proof Vest (with zip), of which the Buyer was not informed, since possibly this problem did not occur in the past to the Seller; furthermore the Buyer asked the Seller to dispose otherwise the remaining quantity of Bullet-Proof Material $(29,871 \mathrm{~lm})$ since this quantity was not really necessary for the materialisation of the Bullet-Proof Material Sale Contract. Then the Seller acknowledged that the problem in the design of the Bullet-Proof Material with the specific design of some Bullet-Proof Vests (with zip) was not new to the Seller and this was confirmed in the ballistic tests that took place on 30.10.2002 and 1.11.2002 ${ }^{16}$ where it was found that the problem was not caused by the Bullet-Proof Material, but by the combination of the specific design of the Bullet-Proof Vests (manufactured from Bullet-Proof Material) and the type of specific ammunition that caused the problem. The Seller further confirmed that it had a suspicion that the design of the Bullet-Proof Vest and the type of ammunition used may have a decisive effect on the performance of the Bullet-Proof Material even if the latter as raw material is of the best quality, and once again confirmed that the Bullet-Proof Material delivered to the Buyer fully satisfied the specifications set out for it. ${ }^{17}$ Then the Seller: (i) made clear that there was no interconnection between the quality of the Bullet-Proof Material and the performance of the Bullet-Proof Vests, (ii) expressed its disappointment since the Buyer did not liaise in order to resolve the problem by providing a defective Bullet-Proof Vest to the Seller and the ammunition used in order for the Seller to make a test; (iii) asked the Buyer to pay the three outstanding invoices of an aggregate amount of $€ 438,771.58$; and (iv) declared that the

\footnotetext{
15. See supra 98.

16. See supra 98 .

17. See supra $₫ 2$.
} 
Seller would not accept the cancellation of the delivery of the $29,871 \mathrm{~lm}$ of Bullet-Proof Material for which the Buyer had placed an order (and thus the Buyer was obliged to take delivery of the $29,871 \mathrm{~lm}$ of Bullet-Proof Material still to be delivered under the Bullet-Proof Material Sale Contract). Then the Seller requested payment of the outstanding amount of $€ 438,771.58$ and informed the Buyer that it had found alternative solutions for the problem in connection with the Bullet-Proof Vest. The Buyer did not answer.

I. Ballistic Test by the Seller in a Certified Laboratory in the NetherlandsOffer by the Seller to Remedy the Problem of the Bullet-Proof Vests with the Adding of Improving Material

10. From a number of letters it resulted that the Seller had proceeded at its own expense to a ballistic test at a certified international laboratory in the Netherlands where it used a model of the Bullet-Proof Vest that the Buyer (State Weapon Subsidiary Co.) had manufactured and delivered to the Authority. At this ballistic test, tenths of shots were performed with stronger ammunition in particular along the gap which existed at the point that the two front parts of the Bullet-Proof Vest are unified and it was found that no problem existed (there was no penetration). Then, an improving material was added with further positive results and a representative of the Seller (Dutch Supplier) delivered samples of this improving material to a representative of the Authority, provided information as to its characteristics (that is 24 grams, $€ 0.33$ price per vest) and at the same time indicated the manner of use which was simple and practical.

J. Refusal of the Buyer to Use the Improving Material Suggested by the Seller in Order to Remedy the Problem of the Bullet-Proof Vests-Purchase by the Buyer of Different Improving Material

11. The Buyer did not manufacture samples of Bullet-Proof Vests with the improving material that the Seller suggested..$^{18}$ On the opposite the Buyer invited the Authority to participate in tests with a different improving material (aramidic fibers, Kevlar). On 27.10.2003 the Buyer eventually concluded an agreement for the purchase of such different bullet-proof material (aramidic fibers, Kevlar) from a different supplier in order to repair (by adding this bullet-proof material) the 6,900 Bullet-Proof Vests that had already

18. See supra $\uparrow 10$. 
manufactured and delivered to the Authority and to manufacture the remaining 1,020 Bullet-Proof Vests on the basis of such different bullet-proof material. Accordingly, although the Failure Analysis ${ }^{19}$ suggested to replace the vest chest manufactured from Bullet-Proof Material with a vest made of Twaron CT709wrt, the Buyer proceeded with the purchase of a different material (aramidic fibers (Kevlar)), from another manufacturer, although it had tested and rejected the latter material at the tests that took place in G. University for the selection of material at the international tender stage. ${ }^{20}$

\section{K. Definite Refusal of the Buyer to Pay the Outstanding Purchase Price and Take Delivery of the Remaining Quantity of Bullet-Proof Material}

12. On 18.3.2004, the Buyer repeated to the Seller that the Authority did not accept the Bullet-Proof Material due to the penetration of the Bullet-Proof Vest at the ballistic tests of 20.9.2002 21 and it demanded from the Buyer the repair of the 6,900 Bullet-Proof Vests that had already been delivered to it. Furthermore, following (i) deduction of the amount of $€ 202,722$ as expenses for the repair of the 6,900 Bullet-Proof Vests and (ii) set-off the advance payment and the expenses for the tests, the Buyer concluded that it owed to the Seller a remaining amount equal to $€ 34,464.45$ and it offered to pay this amount (which it eventually did not). Finally on 21.4.2004, the Seller, by means of a letter to the Buyer, denied any claim of the Buyer, and declared that if the Buyer did not discharge the outstanding amount of $€ 438,771.58$ and did not take over the remaining 29,871 $\mathrm{lm}$ of Bullet-Proof Material corresponding to the amount of $€ 484,770.48$ (out of which it had already prepaid the amount of $€ 194,914.26$ ), it would recourse to justice.

\section{Seller's Action-Legal Issues and Substance-Court's JUDGMENT-COMMENTARY}

\section{A. Seller's Action}

13. The Seller filed an action against the Buyer and requested that the latter would be obliged to pay the total amount of $€ 729,627.58$ out of which:

\footnotetext{
19. See supra $₫ 8$.

20. See supra $\llbracket 2$.

21. See supra $₫ 7$.
} 
(i) the following amounts, i.e. $€ 53,175.29, € 239,537.09$ and $€ 146,059.20$ on account of the three unsettled invoices; ${ }^{22}$ and

(ii) the amount of $€ 290,856.22$ as the consideration for the last quantity of BulletProof Material (11th shipment of 29,871 lm) that the Buyer did not take delivery of. $^{23}$

In particular, as regards the above request, the Seller refers the following in his action:

[T]hat the Buyer, despite the fact that it never claimed that the Bullet-Proof Material supplied by the Seller did not meet the conditions of the Bullet-Proof Material Sale Contract thus clarifying from the start that the problem discovered in the Bullet-Proof Vests manufactured for the Authority was due to the inappropriate design thereof and not the quality of the Bullet-Proof Material, by invoking (the Buyer) that it did not receive payment from the Authority nor was it reimbursed for the cost of repairing the BulletProof Vests, it refused to settle the price of the quantity of Bullet-Proof Material delivered by the Seller and to accept the delivery of the last order (instalment) of BulletProof Material, thus (the Seller) sustaining positive and negative (sequential) losses (damages) which amounts to a total of $€ 729,627.58 .{ }^{24}$

In addition, the Seller requested the Buyer to pay to it the amount of $€ 500,000$ as compensation for moral damages sustained (damage to its international reputation) since:

(i) the fact that the Buyer illegally declared the Bullet-Proof Material Sale Contract concluded between it and the Seller avoided, in conjunction with the conclusion of a new agreement with another supplier-competitor, ${ }^{25}$ resulted to the Seller's forced removal from the relevant market and to damage to its international reputation; and

(ii) the Buyer, following its unjustified replacement from the Seller, stated in practice to any recipient in the Greek and the international market that the failure (penetration of the Bullet-Proof Vest) was due to a certain problem of the Bullet-Proof Material supplied by the Seller and not to a defect in the design and manufacture of the Bullet-Proof Vests by the Buyer,

and as a result of the above behaviour of the Buyer and its defamatory statements, the Seller sustained moral damages for the restitution of which the Seller is entitled to monetary satisfaction. ${ }^{26}$

22. See supra 9 व 6, 12 .

23. See supra $\uparrow \uparrow 9,12$.

24. Judgment $4505 / 2009$ at $30-31$.

25. See supra 911.

26. Judgment $4505 / 2009$ at 31 . 


\section{B. Judgment of the Court on the Seller's Action}

\section{(1) Applicable Provisions}

14. In connection to the request of the Seller for the payment of $€ 729,627.58^{27}$ the court judged that the action was legally grounded based on articles $1, \S \S 1(\alpha), 3,4,6,7,9,25,30,31,33,35,53,57,58,59,61,62,66$, $67,69,74,78,99$ and 100 of the CISG. ${ }^{28}$

(2) Seller's Action: Application of the CISG in the Bullet-Proof Material Sale Contract

15. The Court rightly judged that the Bullet-Proof Material Sale Contract ${ }^{29}$ was governed by the CISG since on one hand, the Seller had its principal place of business in the Netherlands and the Buyer had its principal place of business in Greece (both Netherlands and Greece were Contracting States $)^{30}$ and on the other, during the time the Bullet-Proof Material Sale Contract was concluded (4.7.2001), the Vienna Convention had already been put into place in the Netherlands and Greece. ${ }^{31}$ Furthermore, the Vienna Convention applied in accordance with article 1, § 1(b) of the CISG. More specifically, the Court rightly pointed out that "in case the parties selected the law of a country to be the applicable law, the provisions of the Vienna Contract apply, to the extent that it has been ratified by this specific country." 32 Based on the actual facts, the court concluded that pursuant to clauses 8.3 and 8.4 of the Bullet-Proof Material Sale Contract, the contracting parties had agreed that Greek law would be the substantial and procedural applicable law for the Bullet-Proof Material Sale Contract. ${ }^{33}$ In view of the

27. See supra 913 .

28. The legal part of Judgment 4505/2009 includes numerous recitals of principles of law together with extensive references to Greek legal doctrine and case law; for translated excerpts of these recitals see Flambouras, supra note 3, at $\S \S 2.1-2.4 .1 \& 3$.

29. See supra 94.

30. See United Nations Convention on Contracts for the International Sale of Goods art. 1, § 1(a), U.N. Doc. A/CONG.97/18, Annex 1 (Apr. 11, 1980) [hereinafter CISG].

31. Judgment 4505/2009 at 9-10 systematically set out the subjective, objective, local and time conditions for the application of CISG; for English translation of the relevant excerpts, see Dionysios Flambouras, Editorial Remarks to Judgment 4505/2009, § 2.2.4, available at http://cisgw3.law.pace.edu/ cases/094505gr.html. See CISG art. 99, 100.

32. Judgment $4505 / 2009$ at $9-10$.

33. Id. at 54 . 
above, since Greece had ratified the Convention, the latter applied to the Bullet-Proof Material Sale Contract also in accordance with article 1, § 1(b) CISG. $^{34}$

\section{(3) Seller's Action: Non-Pecuniary Damage—Court's Judgment on Legal Issues}

16. In connection to the request of the Buyer for monetary compensation due to moral distress suffered by it, the court, in our opinion, rightly judged that the action was not legally grounded to the extent that it was based on the CISG provisions. In order to support this judgment the Court invoked the following arguments: (i) that the non-pecuniary damage is not recovered under the CISG; ${ }^{35}$ and (ii) that based on the theory of foreseeability applied in the CISG, the Buyer could not have foreseen (subjective foreseeability) neither was he obliged to had foreseen (objective foreseeability) the invoked damage to the professional reputation of the Seller as a possible consequence of the contractual breach at the time the agreement was concluded. ${ }^{36}$

34. See Oberlandesgericht [Appellate Court of Stuttgart] Germany 31 Mar. 2008, available at http://cisgw3.law.pace.edu/cases/080331g1.html; The Travellers Property Cas. Co. of America and Hellmuth Obata \& Kassabaum, Inc. v. Saint-Gobain Technical Fabrics Canada Limited, 2007 WL 313591 (D. Minn. 2007), available at http://cisgw3.law.pace.edu/cases/070131u1.html. See also BP Oil Int'1, Ltd. v. Empresa Estatal Petroleos de Ecuador, 332 F.3d 333 (5th Cir. 2003), CLOUT Case No. 575 [Court of Appeals [5th Circuit] United States, 11 June 2003], available at http://cisgw3.law.pace.edu/cases/ 030611 u1 .html ("A signatory's assent to the CISG necessarily incorporates the treaty as part of that nation's domestic law [. . .] Where parties seek to apply a signatory's domestic law in lieu of the CISG, they must affirmatively opt-out of the CISG.").

35. Judgment 4505/2009 at 35. On the same opinion, see Anastássios Valtoudis, Liability for Damages pursuant to the Vienna Convention (foundation, discharge from liability and extent of damages), Northern Greece Law Union [ENOBE] 71-72 (2001). Ingeborg Schwenzer, Commentary on the UN Convention on the International Sale of Goods (CISG) 1015 (Peter Schlechtriem \& Ingeborg Schwenzer eds., $3 \mathrm{~d}$ ed. 2010) ("damages which are purely non-pecuniary may be recoverable where the intangible purpose of performance became part of the contract, rendering the loss incurred a typical consequence of non-performance"). $C f$. Oberlandesgericht [Court of Appeal of Linz] Austria, 23 Jan. 2006, available at http://cisgw3.law.pace.edu/cases/060123a3.html (“Art. 25 CISG also applies to other kinds of damage, e.g., [ . . ] a detriment to the reputation of the well-performing party.").

36. Judgment $4505 / 2009$ at $17,18,35$, (where the criteria for subjective and objective foreseeability are analysed extensively; more specifically the following principle is stated: "Thus non-pecuniary damage is not recoverable, as well as damage sustained by a contracting party to its professional reputation and damage from loss of clientele due to the non-compliance by its counterparty with the terms of the sale contract, since this damage is not considered normally foreseeable." For an English translation in English of the relevant excerpts see Dionysios Flambouras, Editorial Remarks to Judgment 4505/2009, § 2.2.11, available at $\mathrm{http}: / /$ cisgw3.law.pace.edu/cases/094505gr.html. 
(4) Seller's Action: Buyer's Allegation (Objection) Regarding Lack of Conformity of the Bullet-Proof Material to the Requirements of the BulletProof Material Sale Contract

\section{(i) Buyer's Allegation}

17. The Buyer alleged that the Seller "at the time the risk was transferred did not comply with the terms of the Bullet-Proof Material Sale Contract, ${ }^{37}$ since on 20.9.2002, during the process of ballistic tests for the Bullet-Proof Vest and of the taking of delivery, ${ }^{38}$ the committee of quality assurance verified that the Bullet-Proof Vests presented penetration during the ballistic tests and therefore the action (of the Seller) should be rejected." ${ }^{39}$

(ii) Court's Judgment Confirming That the Buyer's Allegation on Lack of Conformity Was an "Objection" (Enstasi)

18. The Court rightly judged that the above allegation of the defendant

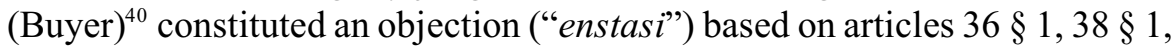
39,60 case (b) and 67-69 CISG and therefore it was the Buyer who should prove the legal and substantial grounds of this allegation. The Court based its conclusion on the fact that after the Buyer took delivery of the ten earlier quantities of the Bullet-Proof Material, ${ }^{41}$ it did not conduct any examination on these received quantities within as short a period as is practicable in the circumstances $^{42}$ neither did it (the Buyer) notified the lack of conformity to the Seller within a reasonable period of time. ${ }^{43}$ That is why (i.e. due to the noncompliance with the above duties) the Buyer was unable to reverse the burden of proof in order for the Seller to be the one who should then prove that, at the time the risk was transferred, the Bullet-Proof Material was in conformity to the Bullet-Proof Material Sale Contract. ${ }^{44}$ The fact that the Court cited the

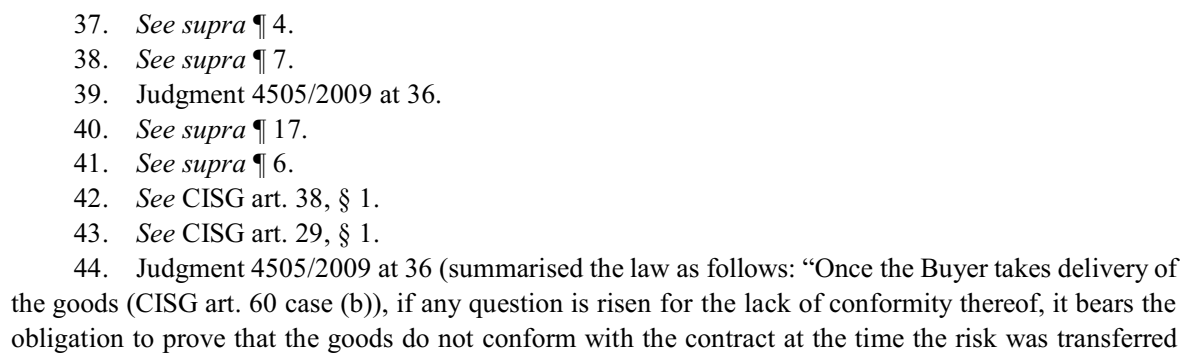


relevant CISG provisions leads to the conclusion that it followed the opinion pursuant to which the burden of proof relating to non-conformity of the goods with the contract of sale is a matter falling within the scope of the CISG. ${ }^{45}$

(CISG art. 36, $\S § 1$ and 67-69). Nevertheless, if the Buyer, after taking delivery of the goods, examines them within as short a period as is practicable in the circumstances (CISG art. 38, 1 ), and discovers the lack of conformity, and notifies the said lack of conformity to the Seller within a reasonable period of time determining the exact nature thereof (CISG art. 39), for which it certainly bears the burden of proof, then the burden of the proof is reversed and the Seller is obliged to prove that at the time the risk was transferred the goods were in conformity with the contract.”). See Rechtbank [District Court of Breda] Netherlands, 16 Jan. 2009, available at http://cisgw3.law.pace.edu/cases/090116nl.html; Norfolk S. Ry. Co. v. Power Source Supply, Inc., 2008 WL 2884102 (W.D. Pa. 2008), available at http://cisgw3.law.pace.edu/cases/ 080725ul.html; Landgericht [District Court of Bamberg] Germany, 23 Oct. 2006, available at http:// cisgw3.law.pace.edu/cases/061023g1.html; Chicago Prime Packers, Inc. v. Northam Food Trading Co., 408 F.3d 894, 898 (7th Cir. 2005), available at http://cisgw3.law.pace.edu/cases/050523u1.html ("under the CISG, the buyer-defendant bears the burden of proving non-conformity at the time of transfer (i.e. of risk)"); Bundesgericht [Supreme Court] Switzerland, 7 July 2004, available at http://cisgw3.law.pace.edu/ cases/040707s1.html; Bundesgerichtshof [Federal Supreme Court] Germany, 9 Jan. 2002, available at http://cisgw3.law.pace.edu/cases/00109g1.html. See also Anastássios Valtoudis, On the problem of concurrence of liability for real defects pursuant to the Vienna Convention (CISG) with the national non-

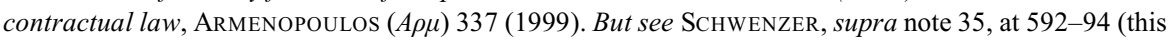
Author initially states that "once the buyer has physically taken over the goods, he generally has to prove their non-conformity at the time of passing of risk [and ... .] if the buyer rejects the goods or notifies the seller of their non-conformity immediately at the time of taking over, the seller has to prove that the goods were in conformity with the contract"; however, then she goes on by stating that "[T] $]$ he further reaching approach of imposing the burden of proof on the seller in all cases in which the buyer gives timely notice of non-conformity pursuant to Article 39, has to be rejected"). On the burden of proof under CISG art. 35, see Anna Linne, Burden of Proof Under Article 35 CISG, 20 PACE InT'L L. Rev. 31 (2008).

45. See Bundesgerichtshof [Federal Supreme Court] Germany, 9 Jan. 2002, available at http:// cisgw3.law.pace.edu/cases/00109g1.html ("the burden of proof is a matter governed by the CISG expressly (CISG 79, § 1) or impliedly (CISG 2 case a)"); Chicago Prime Packers, 408 F.3d at 898. Furthermore it is suggested that the CISG includes a general principle (applicable by virtue of CISG art. 7, §2) on the basis of which each contracting party has the burden to prove the facts that support its right, its claim or a possible objection, that is any facts to its benefit. See P. Huber, Some Introductory Remarks on the CISG, Internationales Handelsrecht 228, 234 (2006); P. Kornilakis, A Dogmatic Approach to the New Provisions-The Concept of Fundamental Contractual Breach, Nor THERN GREECE LAW UNION(ENOBE) 14 (2001); P. Arvanitakis, The Effect of the Vienna Convention for the International Sale of Goods to the

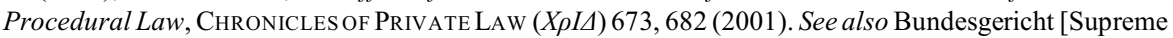
Court] Switzerland, 7 July 2004, available at http://cisgw3.law.pace.edu/cases/040707s1.html ("The allocation of the burden of proof between the parties is regulated by the CISG. In case an explicit rule is not available, a court has to resort to the general principles underlying the Convention. As one of these principles, it must be taken into account how close each party is to the relevant facts at issue, i.e., a party's ability to gather and submit evidence for that point. Hence, if a buyer takes on a delivery without giving notice for any claimed deficiencies, thus establishing its exclusive possession of the goods, then it, the buyer, has to prove any claimed lack of conformity of the delivered goods"); SCHWENZER, supra note 35, at 592 ("The allocation of the burden of proof follows from the principle of 'the rule and exception' and the principle of proximity of proof."). 
(iii) Court's Judgment Confirming That One Month Is Considered a Reasonable Period for the Notification of the Lack of Conformity in the Context of Article 39, \& 1 CISG

19. We consider that above judgement of the $\mathrm{Court}^{46}$ is correct. Indeed, if the goods sold do not conform to the sale contract during the time the risk was transferred, ${ }^{47}$ then the Buyer is obliged to examine the goods within as short a period as is practicable in the circumstances and notify the said lack of conformity to the Seller within a reasonable period of time, otherwise the Buyer is deprived of the ability to exercise the legal remedies provided for the lack of conformity under articles 38 and $39 \mathrm{CISG}^{48}$ subject of course to the exception set out in CISG article $40 .{ }^{49}$ The Court, consistent with the findings of a substantial part of foreign case law, considered the period of one (1) month as a reasonable period for the notification of the lack of conformity for the purposes of article 39 CISG. $^{50}$ It should be noted though that the Court

46. See supra $\llbracket 18$

47. See infra $\uparrow 28$.

48. Judgment 4505/2009 at 36 (summarised the law as follows: "Legal remedies of the Buyer for the non-conformity of the goods to the contract's requirements (CISG 35), may be exercised, only if the Buyer has observed the obligations provided for by the CISG, i.e., (a) examination of the goods within as short a period as is practicable in the circumstances (CISG 38, $\S 1$ ); and (b) notification of the lack of conformity to the Seller, with detailed description of the nature of the lack of conformity within a "reasonable" period of time from the moment the Buyer discovered or ought to had discovered the lack of conformity, which [reasonable period] is deemed that of one (1) month [. . .] and in any case within two years from the date actual delivery of the goods was effected to the Buyer."). Cf. Oberlandesgericht [Appellate Court of Linz] Austria, 23 Jan. 2006, available at http://cisgw3.law.pace.edu/cases/ 060123a3.html; Cour de Justice [Appellate Court of Geneva] Switzerland, 20 Jan. 2006, available at http://cisgw3.law.pace.edu/cases/060120s1.html.

49. See supra $\uparrow 27$.

50. In connection with the reasonableness of a time period for the purposes of CISG article $39, \S 1$. See Tribunale [District Court of Forli] Italy, 11 Dec. 2008, available at http://cisgw3.law.pace.edu/ cases/081211i3.html (1 week); Oberlandesgericht [Appellate Court of Köln] Germany, 19 May 2008, available at $\mathrm{http} / / / \mathrm{cisgw} 3.1$ aw.pace.edu/cases $/ 080519 \mathrm{~g} 1 . \mathrm{html}$ (5 months is not a reasonable period); Oberlandesgericht [Appellate Court of Hamburg] Germany, 25 Jan. 2008, available at http://cisgw3.law .pace.edu/cases/080125g1.html (14 days-1 month); Regional Court of Zilina Slovak Republic, 25 Oct. 2007, available at http://cisgw3.law.pace.edu/cases/071025k1.html (3 months since the defect could only be found if the sold cloth was worn); Landgericht [District Court of Bamberg] Germany, 23 Oct. 2006, available at http://cisgw3.law.pace.edu/cases/061023g1.html (1 month); Cour de Justice [Appellate Court of Geneva] Switzerland, 20 Jan. 2006, available at http://cisgw3.law.pace.edu/cases/060120s1.html (1 month); Bundesgericht [Federal Court] Switzerland, 3 Nov. 2003, available at http://cisgw3.law.pace.edu/ 031113s1.html (1 month); Bundesgerichtshof [Federal Supreme Court] Germany, 8 Mar. 1995, available at http://cisgw3.law.pace.edu/cases/950308g3.html (1 month); see also SchwENZER, supra note 35, at 629-33 (with extensive references to case law and in particular "a period of approximately one month 
does not appear to adequately justify its conclusion that the Buyer "did not conduct any examination of the quantities delivered within as short period as is practicable in the circumstances" and therefore that it did not observe the duty provided by article 38 CISG. ${ }^{51}$ In particular, there is academic opinion that as a rule, two periods must be distinguished, namely the period for examining the goods and the period for giving notice of lack of conformity and that these periods should not be combined to make a total period. ${ }^{52}$ On this basis the Court should had specifically considered whether, under the circumstances, the Buyer had examined the received Bullet-Proof Material in the manner required under article 38 CISG. Recent case law however suggests that prior examination within the context of article 38 CISG is not to be seen as a requirement for an effective notice of non-conformity (within the context of article 39 CISG) and thus, if the buyer gives timely notice of the lack of conformity of the goods in the sense of article $39 \S 1$ CISG, it is irrelevant whether the examination has taken place within reasonable time and in reasonable form..$^{53}$

\section{(iv) Bullet-Proof Material Sale Contract: An Instalment Contract}

20. In the case in question it is clear that certain particularities exist, since the Seller was obliged to deliver the sold Bullet-Proof Material in instalments (in ten "shipments") at different times, ${ }^{54}$ furthermore, each delivery ("shipment") of Bullet-Proof Material was independent (severable) from the other deliveries ("shipments") and was independent (severable) in relation to the Bullet-Proof Material Sale Contract as a whole. On this basis the BulletProof Material Sale Contract was an instalment contract. ${ }^{55}$ It is worth noting

\footnotetext{
should at least be adopted as a rough average. In recent times the case law in Germany and Switzerland would appear to be approaching this average." $I d$. at 632 . The 1 month period criterion has not been followed though by many cases. $C f$. Oberlandesgericht [Appellate Court of Schleswig] Germany, 22 Aug. 2002, available at $\mathrm{http} / / / \mathrm{cisgw} 3$.law.pace.edu/cases/020822g2.html (in relation to livestock three or four days or shorter under specific circumstances of the particular case); Sky Cast, Inc. v. Global Direct Distribution, LLC, 2008 WL 754734 (E.D. Ky. 2008), available at http://cisgw3.law.pace.edu/cases/ $080318 \mathrm{u} 1 \mathrm{html}$ (reasonable period of 10 months and in any event within the two year period of $39, \S 2$ ); Monomeles Protodekeo [Single Member First Instance Court of Thessaloniki] Greece, 2003, available at http://cisgw3.law.pace.edu/cases/030001 gr.html (reasonable period of $2 \frac{1}{2}$ months).

51. Judgment 5450/2009.

52. SCHWENZER, supra note 35 , at 629 .

53. Landgericht München [District Court of Munich] Germany, 29 Nov. 2005, available at http://cisgw3.law.pace.edu/cases/051129g1.html.

54. See supra $₫ \uparrow 4,6$.

55. CISG art. 73. See Christiana Fountoulakis, Commentary on the UN Convention on the
} 
that the Court referred only once, within the context of the Buyer's Action against the Seller, to the nature of the Bullet-Proof Material Sale Contract as an instalment contract and the consequences related to this characteristic with an emphasis on prescription issues. ${ }^{56}$ In particular the Court, correctly in our opinion, judged that the Bullet-Proof Material Sale Contract was an instalment contract for the delivery of goods, since the instalments ("shipments") of Bullet-Proof Material were self-existent as compared among them. ${ }^{57}$ It should be noted that the above conclusion of the Court (i.e. that the Bullet-Proof Material Sale Contract was an instalment contract), is further supported by the fact that, until the discovery of the malfunction in the Seller's Bullet-Proof Material in September 2002, the Buyer had already used the Bullet-Proof Material of the ten instalments ("shipments") that the Seller had delivered to it in order to manufacture Bullet-Proof Vests and the Buyer had already delivered to the Ministry around 6,900 Bullet-Proof Vests. ${ }^{58}$ By means of commentary it is noted that the Court made no reference to the fact that the instalments were self-existent not only as compared among them, but as regards the Bullet-Proof Material Sale Contract as a whole, as it is accepted - in terms of interpretation - that should apply in the context of the CISG in order for an instalment contract to exist. ${ }^{59}$ Furthermore, it would be preferable if the Court, for the purpose of categorising as instalment contract the Bullet-Proof Material Sale Contract, had expressly referred to the criteria of article 8 CISG (interpretation of the agreement in question and the parties' statements) and not, as it did, to the views of domestic legal doctrine within the context of interpretation of the Greek Civil Code; besides, this necessity for recourse to article 8 CISG derives from article $7, \S 1$ CISG which calls for

International SALE of Goods (CISG) 986-87 (Peter Schlechtriem \& Ingeborg Schwenzer eds., 3d ed. 2010) ("The question of whether the case involves an instalment contract or several unrelated contracts depends on whether the transaction is to be regarded as a unit. In order to qualify as an instalment contract, the sum of its subdivided unities must form a single whole. Factors indicating such a unit are a logical and/or economic intertwinement of the deliveries; the contract appears to be unfinished or incomplete as long as some deliveries are missing"). Cf. also Rosa Hornung, CoMmentary on the UN CONVENTION on the International Sale of Goods (CISG) 733 (Peter Schlechtriem \& Ingeborg Schwenzer eds. 2d ed. 2005) (“ $\ldots$ at least two deliveries are required for such contract (i.e. instalment) to exist. The decisive feature is the difference in time between the first and later deliveries, because that is why special remedies are needed for this type of contract. Individual deliveries must be severable from each other and be independent of the overall contract in such a way that they can be called instalments.").

56. See infra $₫ 42$.

57. Judgment 4505/2009 at 53 .

58. See supra $\llbracket 11$.

59. See supra note 55 . 
independent interpretation of the Convention's provisions without recourse to domestic provisions and legal doctrine opinions on domestic law. ${ }^{60}$

From the nature of the Bullet-Proof Material Sale Contract as an instalment contract a basic question arises being what is the point of time when the reasonable period of one month for the notification of the lack of conformity commences, ${ }^{61}$ if lack of conformity of the goods in an instalment contract is discovered.

(v) Remedies Exercised by the Buyer in Connection with the Alleged Lack of Conformity

21. In order to respond to the above question ${ }^{62}$ it has to be examined which legal remedy was exercised by the Buyer for the lack of conformity with the Bullet-Proof Material Sale Contract of the quantity of the BulletProof Material sold and which part (parts) instalment(s) of the quantity concerned the exercise of the said legal remedy. From the actual facts as set out in Judgment 4505/2009, it can be concluded at first, that the last date the Buyer took delivery of the Bullet-Proof Material was 19.7.2002, while, during the period from 11.1.2002 to 19.7.2002, the Seller delivered in ten instalments ("shipments") to the Buyer, a quantity of Bullet-Proof Material which amounted to a total of $125,129 \mathrm{~lm} .{ }^{63}$

Furthermore, from the text of Judgment 4505/2009 the following can be concluded: ${ }^{64}$

(i) The Buyer settled invoices corresponding to the first six instalments ("shipments") and paid the total amount of $€ 779,650$ as the respective price.

(ii) The Buyer finally did not settle three invoices which corresponded to three instalments ("shipments") (No. 13196/30.5.2002 (shipment No. 7), 13.439/19.7.2002 (shipment No. 9) and 13440/19.7.2002 (shipment No. 10)) which corresponded to a quantity of Bullet-Proof Material of a total value $€ 438,771.58$.

60. See Michael Joachim Bonell, Commentary on the International Sales Law: The 1980 Vienna Sales Convention Giuffré, Milan $72-73$ (C.M. Bianca \& M.J. Bonell ed., 1987); Larry A. DiMatteo et al., The Interpretative Turn in International Sales Law: An Analysis of Fifteen Years of CISG Jurisprudence, 24 Nw. J. INT'L L. \& Bus. 299, 311 (2004).

61. See CISG art. 39.

62. See supra $\llbracket 20$.

63. See supra 9 6. See also Judgment $4525 / 2009$ at 76.

64. See supra $\uparrow$ ๆ $6,11,12$. 
Another issue is raised as to the legal grounds based on which the Buyer refused to pay the unsettled price. In particular, in a facsimile dated 18.3.2004 ${ }^{65}$ to the Seller, the Buyer repeated that the Authority rejected the Bullet-Proof Material of the Seller due to penetration of a Bullet-Proof Vest in the tests conducted on 20.9.2002 ${ }^{66}$ and that it demanded the repair of all Bullet-Proof Vests that the Buyer delivered to it and, after the Buyer would deduct the amount of $€ 202,722$ which corresponded to the cost for repairing the Bullet-Proof Vests as requested by the Authority and set-off the advance payment and the tests costs, it finally concluded that it owed to the Seller the amount of $€ 34,464.45$, which it was willing to pay, but it never did so.

22. From the above facts the following could be suggested:

(a) One possibility is that the Buyer declared avoided the three instalments ("shipments") of Bullet-Proof Material already delivered to it (no. 7, 9 and 10) by refusing to pay the unsettled part of the price corresponding to these instalments since, based on Buyer's allegations, the Bullet-Proof Material did not comply with the contractual description under the Bullet-Proof Material Sale Contract. Accordingly within the context of an instalment contract the Buyer declared three delivered instalments avoided due to fundamental breach ${ }^{67}$ and its intention to declare the instalments avoided was most probably evidenced by its behaviour (i.e. definite refusal of the Buyer to pay the corresponding price, conclusion of a contract on 27.10.2003 for the purchase of different bullet-proof material from another supplier) ${ }^{68}{ }^{69}$ It needs to be noted though that

65. See supra $\llbracket 12$.

66. See supra 97.

67. See CISG art. 73, § 1, 45, § 1(a), 25, 81 .

68. See supra $\uparrow 11$.

69. It is suggested that where the conduct of the party shows clearly the intention to terminate the contract and where the conduct is communicated to the party in breach, this should suffice (being an implicit declaration of avoidance) to effect avoidance of contract due to the general principle of freedom of form enshrined in article 11 CISG. See Ulrich Magnus, The Remedy of Avoidance of Contract Under CISG-General Remarks and Special Cases, 25 J.L. \& CoM. 423, 427 (2005); Christopher M. Jacobs, Notice of Avoidance under the CISG: A Practical Examination of Substance and Form Considerations, the Validity of Implicit Notice, and the Question of Revocability, 64 U. PITT. L. REv. 407, 417 (2003) ("the more clearly the given conduct suggests an intention to avoid, the more unnecessary it will be to require formal notice"). However, the above opinion is strongly doubted since "the wording of Article 26 stems from the rejection of the ipso facto avoidance." Id. at 417; see FounTOULAKIS, supra note 55, at 442 (who correctly states that avoidance of contract without declaration is of particular relevance with regard to the calculation of damages under articles 75 or 76 CISG). See also Court of Arbitration of the International Chamber of Commerce No. 99788/1999, Mar. 1999, available at http://cisgw3.law.pace.edu/cases/ 999978i1.html. (It is, however, one of the major characteristics of the UN Sales Convention, when 
the Buyer's subsequent behaviour appeared rather contradictory in relation to its intention to avoid these three instalments since, within the context of the Seller's Action proceedings, the Buyer denied to pay the amounts claimed by the Seller (including the price for these three instalments) by suggesting set-off, i.e. by alleging that it had against the Seller due and payable counter-claims of the same kind (i.e. monetary) arising, inter alia, from its right to demand compensation from the Seller. ${ }^{70}$ Despite the above contradictory behaviour of the Buyer which leaves a degree of uncertainty as to whether the Buyer had declared instalments no. 7, 9 and 10 avoided or not the examination of the Buyer's entitlement to declare these instalments avoided raises important legal questions and grants incentive for interesting commentary.

On this basis, the Buyer would not be entitled to declare instalments no. 7, 9 and 10 avoided for various reasons. Firstly, as the Court accepted, the delivered quantities of Bullet-Proof Material were in conformity with the Bullet-Proof Material Sale Contract and therefore there was no fundamental breach of contract by the Seller. ${ }^{71}$ Secondly, even if it was assumed that there was fundamental breach due to the non-conformity of the Bullet-Proof Material, the Buyer could had lost its right to declare instalments no. 7, 9 and 10 avoided since it was impossible for it to make restitution of the Bullet-Proof Material in the condition in which it received it (i.e. the quantities of the Bullet-Proof Material delivered as instalments 7, 9 and 10 had been transformed because they had been used as raw material for the manufacture of Bullet-Proof Vests under the BulletProof Vests Manufacturing Contract and then delivered to the Authority under the Bullet-Proof Vests Supply Contract). ${ }^{72}{ }^{73}$

compared to its predecessors, the Hague Sales Convention of 1964, that international sales contracts are not invalidated ex lege but only in case of a clear and unambiguous declaration of avoidance by one of the parties pursuant to Art. 26 CISG. For this reason a notice of avoidance under Art. 26 CISG must satisfy a high standard of clarity and precision [ . . . ] however, Claimant has made it clear to Respondent that it demands repayment of the amounts paid under the $\mathrm{L} / \mathrm{C}$. This declaration satisfies the strict standard to be applied under Art. 26 CISG. It does not matter that Claimant did not use the technical terms "avoidance" or "avoid." Declarations of avoidance under Art. 26 CISG may be made implicitly, provided that it is made clear to the other party that the party entitled to avoidance does not intend to stand by the contract any more.)

70. See infra $₫ 30$.

71. See infra $₫ 48$.

72. CISG art. $82, \S 1$.

73. The consequences when one instalment or more under an instalment contract is (are) declared 
Thirdly, the Buyer had not complied with its duties under articles 38 and $39 \mathrm{CISG},{ }^{74}$ and fourthly, the Buyer most probably would had not complied with the requirement set out in article 49, § 2(b) CISG for timely declaration of avoidance which, by means of a general principle, ${ }^{75}$ also applies in connection with the avoidance of one or more instalments under an instalment contract. ${ }^{76}$ Accordingly, since the Buyer was not entitled to declare instalments no. 7, 9 and 10 avoided, it (the Buyer) continued (as accepted by the Court) ${ }^{77}$ owing the price corresponded to these instalments under the Bullet-Proof Material Sale Contract. ${ }^{78}$ Finally it could alternatively be suggested that the Buyer, based on a general principle (article $7, \S 2$ ) deriving from articles 58, 71, $81 \S 2,85(\mathrm{~b})$ and $86 \S 1 \mathrm{CISG}$, exercised its right to withhold (retain) performance $;^{79}$ on this basis the Buyer withheld (retained), at least for some period of time, the performance of its obligation to pay the price for the three instalments since,

avoided are regulated by articles 81 et seq. of the CISG. FounToulaKis, supra note 55, at 989. Harry M. Flechtner, Remedies Under the New International Sales Convention: The Perspective from Article 2 of the U.C.C., 8 J.L. \& Com. 53, 89 (1988) ("The purpose of Article 73(1) . . is to permit a party to treat each installment of an installment contract as a severable contract for the purposes of avoidance."). However, in this case the Buyer would retain all other remedies under the Bullet-Proof Material Sale Contract and the CISG. See CISG art. 83. Furthermore, the Buyer could invoke article 82, § 3 CISG in order to preserve its right to declare instalments no. 7, 9 and 10 avoided, claiming that it transformed the Bullet-Proof Material into Bullet-Proof Vests in the course of normal use (i.e. bullet-proof material is normally used as raw material for bullet-proof clothing) and then the Bullet-Proof Vests were sold in the normal course of business, before it (the Buyer) discovered or ought to have discovered the lack of conformity thereof with the Bullet-Proof Material Sale Contract; in this latter instance though the Buyer would still be obliged to account to the Seller for all benefits which it had derived from the Bullet-Proof Material. See CISG art. 84, $\S 2$ (a). However, such benefits should be net benefits and be retained by the Buyer (e.g., any money received from a sub-buyer does not account as a benefit under the head contract of sale if it has to be returned to the sub-buyer following rejection of the goods, since article 84 CISG concerns only retained benefits). See Michael Bridge, The Nature and Consequences of Avoidance of the Contract Under the UN Convention on the International Sale of Goods, 10 INT'L L. Rev. WuHAN U. 118, 128 (2009).

74. See infra $\llbracket 23$.

75. CISG art. $7, \S 2$.

76. See infra $₫ 24$

77. See infra 931

78. If the contract is not legally declared avoided the parties continue to be obliged to perform their contractual obligations. For the effects of the declaration of the contract avoided in accordance with the law under the CISG, see CISG arts. 81-84 and analytically $c f$. CISG-AC Opinion No. 9, Consequences of Avoidance of the Contract, Rapporteur: Professor Michael Bridge, London School of Economics, London, U.K., Adopted by the CISG-AC in its 12th meeting in Tokyo, Japan on 15.11.2008. Bridge, supra note 73, at $118-28$.

79. On this general principle, see Schwenzer, supra note 35, at 141. 
based on its allegations, the Bullet-Proof Material did not conform to the Bullet-Proof Material Sale Contract. ${ }^{80}$

(b) The Buyer, by means of a facsimile dated 11.2.2003, refused to take delivery, as it was obliged, ${ }^{81}$ of the remaining $29,871 \mathrm{~lm}$ of BulletProof Material (i.e. the 11th instalment-shipment) that worth $€ 290,856.22$, requesting the Seller to "dispose them otherwise" claiming that "they were not truly necessary for the performance of the order contract and that they were ordered (by the Buyer) only in order to reduce the time of the production process." 82 By its above statement, it appears that the Buyer attempted to declare the 11th instalment of $29,872 \mathrm{~lm}^{83}$ avoided after the lapse of the period in which it was obliged to take delivery thereof. Accordingly within the context of an instalment contract the Buyer declared one instalment avoided. ${ }^{84}$ However, the Buyer was not entitled to declare the specific instalment avoided, since it did not invoke a fundamental

80. On the right of a buyer to withhold (retain) performance of its obligation to pay the purchase price due to non-conformity of the goods, see Oberster Gerichtshof [Supreme Court] Austria, 8 Nov. 2005, available at http://cisgw3.law.pace.edu/cases/051108a2.html.

81. In order to legally support this conclusion in Judgment 4505/2009 at 11 the following is stated: The Buyer, on the other hand, bears the main contractual obligation to pay the price to the Seller at its domicile, CISG art. 57, § 1 case (a), within the period set in the sale contract or concluded thereby and which is once the goods or the supporting documents thereof are made available to it, CISG arts. 58, § 1, 59 , and in contrast to the provisions of the Greek Civil Code (GCC), to take delivery of the good, CISG art. 60 , a fact which also constitutes an important innovation of the Convention.

82. Judgment $4505 / 2009$.

83. CISG arts. 53, 60. This, in our opinion, was a statement (within the meaning of CISG art. 26) to declare instalment no. 11 avoided since it showed the Buyer's intention to distance itself from this instalment; this was the case even though the reason stated in this declaration did not actually constitute a contractual breach. See FounTOULAKIS, supra note 55, at 440-41 ("courts and tribunals are often willing to accept a certain conduct as an effective declaration of avoidance, as long as the party's intention to distance itself from the contract is made clear [. . .] the declaration need not mention the ground for avoidance"); Magnus, supra note 69, at 427 ("Though the notice need not expressly mention the term avoidance or termination it must make unambiguously clear that the contract is terminated."); $c f$. Jacobs, supra note 69, at 409 ("the notice should certainly contain the reason for the declaration of avoidance").

84. CISG arts. 73, $\S 1,45, \S 1$ (a), 25, 81. See also supra note 73. It should be noted that, even if the time period for the acceptance of the $29,871 \mathrm{~lm}$ (for the 11th instalment) had not yet lapsed, the Buyer, in view of the known to it penetration to the Bullet-Proof Vest during the tests conducted on 20.9.2002, see supra $\uparrow 7$, could, if there was a failure or a fundamental contractual breach in connection with instalments no. 7, 9 and 10, see CISG art. 25, have declared the contract avoided in connection with future instalment no. 11 under the conditions set out in article 73, § 2 CISG. See John HonNold, UNIFORM Law For INTERNATIONAL SALES UNDER THE 1980 UN CONVENTION 443-44 (3d ed. 1999). However, article 73, § 2 CISG did not apply under the specific circumstances since, it is apparent from the facts, that the time at which the Buyer was obliged to take delivery of the remaining quantity of Bullet-Proof Material had elapsed. See FounToulaKIS, supra note 55, at 992 ("the right to avoid the contract under Article 73(2) is limited to future instalments"). 
contractual breach by the Seller as to this instalment ${ }^{85}$ but (invoked) a rather vague and "cryptic" excuse. In addition, as the Court judged, the Bullet-Proof Material corresponded to the Bullet-Proof Material Sale Contract and thus the Buyer had not breached the contract. ${ }^{86}$ On this basis the Buyer was still obliged, as the Court judged, ${ }^{87}$ to take delivery of the remaining 29,871 lm of Bullet-Proof Material (i.e. the 11 th instalment-shipment $)^{88}$ and pay the respective price. ${ }^{89}$

(c) Within the context of the Seller's Action proceedings the Buyer denied to pay all amounts claimed by the Seller ${ }^{90}$ by suggesting setoff, i.e. by alleging that it had against the Seller due and payable counter-claims of the same kind (i.e. monetary) arising, inter alia, from expenses equal to $€ 655,671.01$ that the Buyer sustained since the Ministry, due to the penetration of the Bullet-Proof Vest at the ballistic tests of 20.9.2002, ${ }^{91}$ refused to take delivery of the remaining units of Bullet-Proof Vests and demanded, under the Bullet-Proof Vests Supply Contract, from the Buyer to repair the delivered Bullet-Proof Vests with the addition of improving material (aramidic/Kevlar). ${ }^{92}$ Accordingly the Buyer raised a claim for compensation of damages suffered due to lack of conformity of the Bullet-Proof Material delivered to it in instalments under an instalment contract. ${ }^{93}$ It is noted that the Court, within the context of the Seller's Claim, adjudicated only in relation to one counter-claim of the Buyer under the set-off objection, ${ }^{94}$ since most of the Buyer's counter-claims were also part of the Buyer's Action against the Seller $^{95}$ where the relevant compensation claim of the Buyer is analysed).

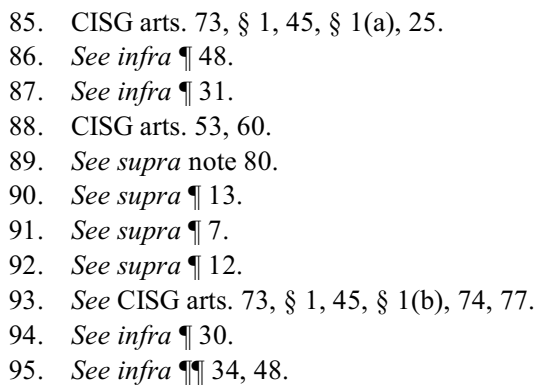


(vi) Time of Commencement of the Reasonable Period for the Notification by the Buyer of the Lack of Conformity

23. As regards the time at which the Buyer notified the lack of conformity to the Seller, the following are concluded: in a meeting held in Athens on 25.9.2002 (i.e. about 8 months after the first delivery of Bullet-Proof Material (11.1.2002) and 1 month and 6 days after the last delivery of the Bullet-Proof Material (19.7.2002)), the Buyer (and the State Weapon Co.) informed the Seller for the first time (whereas on 9.10.2002 a letter from the State Weapon Co. followed) as to the failure (penetration of the Bullet-Proof Vest) which occurred in the ballistic tests held on 20.9.2002 (these were the tests conducted for the acceptance of the end product, i.e. the Bullet-Proof Vests manufactured by the Bullet-Proof Material). ${ }^{96}{ }^{97}$ Therefore, with reference to each of instalments no. 7, 9 and 10 for the delivery of Bullet-Proof Material, if one accepts that the Buyer tried to declare them avoided, ${ }^{98}$ the latter notified the lack of conformity to the Seller, one month and six days after taking delivery of instalments no. 9 and 10 (it took delivery thereof on 19.7.2002) and 3 months and 29 days as regards instalment no. 7 (it took delivery thereof on 30.5.2002) which time periods would be further extended if it was found that the notification was effected by means of the letter of the State Weapon Co. on 9.10.2002. ${ }^{99}$

Consequently, based on the criterion of "one month" adopted by the Court, ${ }^{100}$ the Buyer had not notified the lack of conformity as regards instalments no. 7, 9 and 10 within a reasonable period of time as stipulated by article 39 CISG and this resulted to the following:

(a) The burden of proof was not reversed and the Buyer was still obliged to prove that at the time the risk was transferred the goods were in conformity with the contract. ${ }^{101}$

(b) Even if at the time the risk was transferred there was lack of conformity (which was not though the case) ${ }^{102}$ of the quantities

96. See supra $₫ 7$.

97. Judgment $4505 / 2009$ at 78 .

98. See supra $922(\mathrm{a})$.

99. The requirements for a proper examination of the goods and a notice for their non-conformity pursuant to articles 38 and 39 CISG must be observed with regards to any instalment to be avoided. Fountoulakis, supra note 55, at 989.

100. See supra $\llbracket 9$.

101. See supra $\llbracket 18$, see infra $₫ 28$.

102. See infra $₫ 48$. 
(instalments) of Bullet-Proof Material no. 7, 9 and 10 that the Buyer had taken delivery of in accordance with the Bullet-Proof Material Sale Contract, again the latter would not be entitled to declare them avoided $^{103}$ or demand compensation for the damage it suffered due to the non-conformity of the Bullet-Proof Material with the BulletProof Material Sale contract. ${ }^{104}$

\section{(vii) Limitations Regarding Avoidance?}

24. Furthermore it needs to be noted that even if it could be presumed that the notification for the lack of conformity was served within a reasonable period of time for the purposes of article 39 CISG, again it could be said that the notification to the Seller of the fact that instalments no. 7, 9 and 10 were declared avoided was not served within a reasonable time and therefore the Buyer lost the right to declare them avoided. In particular it could be argued that, when the Buyer declared these three instalments avoided, it violated a general principle of the CISG,${ }^{105}$ the existence of which is concluded from articles $49, \S 2$ and $64, \S 2$ CISG and according to which general principle, subject to any agreement to the contrary between the parties, ${ }^{106}$ a party who is willing to declare avoided an instalment under an instalment contract governed by the CISG, must do so within a reasonable period of time after it knew or could have known its right of avoidance (i.e. the breach). ${ }^{107}$

103. See supra $₫ 22(a)$.

104. See infra 934.

105. CISG art. $7, \S 2$.

106. CISG art. 6.

107. See Fountoulakis, supra note 55, at 988-89 (“an implicit time restriction for the exercise of a right of avoidance is read into art. 26 and this time restriction applies also under art. $73, \S 1$ ”). In particular what constitutes a "reasonable period of time" for the purposes of article 49, §2(b) CISG must be judged according to the circumstances of the particular case and the purpose of article $49, \S 2$ (b) including, among others, the length of the period for giving notice of defects under article $39, \S 1$ CISG, the provisions of the contract, the type of goods and type of defect, as well as the behavior of the seller after notice of defects has been given. See Markus Müller-Chen, Commentary on the UN Convention on the International SALE OF Goods (CISG) 762 (Peter Schlechtriem \& Ingeborg Schwenzer eds., 3d ed. 2010). For the above assessment on what constitutes a "reasonable period of time" one has also to take into consideration whether the facts were complex and as a result detailed legal analysis and advice was necessary in order for the counterparty of the breaching party to assess whether it will exercise avoidance or the potential existence of bank holidays etc. See Oberlandesgeritcht [Appellate Court of Stuttgart] Germany, 31 Mar. 2008, available at http://cisgw3.law.pace.edu/cases/080331g1.html. It is noted that if the buyer cannot satisfy the requirement for timely declaration of the contract set out in article $49, \S 2$ CISG, it will not be able to avoid the contract (or the instalment(s) under an instalment contract) and will be obliged to allow the seller to keep the price or to pay the price (offset in certain circumstances against its (buyer's) claim for damages). See also infra note 75. 
(viii) Article 35 CISG?

25. Within the context of the Buyer's Action, the Buyer based its claim against the Seller for pre-contractual liability. The Court rejected this claim of the Buyer with a number of arguments. One argument was that the Seller in the financial tender submitted to the State Weapon Co. on 14.2.2000 at the pre-contractual stage, pointed out that the Bullet-Proof Material was a new product in the market and did not exist for enough time in order to have real experience data. ${ }^{108}$ Another argument was that the Buyer (and the State Weapon Co.) were obliged to be informed and could had been informed of the fact that the Bullet-Proof Material "behaved" differently according to the design and the bullet-proof vest; this was due to the fact that themselves had extended experience and know-how and also had cooperated in the past (1994) with the Seller and again had purchased the Seller's bullet-proof material thus being aware of its exact specifications. ${ }^{109}$ The Court's acceptance of the above factual assumptions leads to the question whether "there was room left" for the application of article 35, §3 CISG and as a result whether the Buyer had already lost its right to rely on lack of conformity (a question not examined by the Court). In relation to this question the following should be noted: article $35, \S 2$ CISG relates only to cases of lack of conformity under article $35, \S 2$ CISG, not to contractually-agreed qualities of the goods under article $35, \S 1$ CISG. In this instance the Court made reference to both article 35, $\S 1$ and 35, $\S 2$ CISG in order to examine whether the Bullet-Proof Material conformed to the Bullet-Proof Material Sale Contract. ${ }^{110}$ On this basis the possibility that article 35, § 3 CISG was applicable under the specific facts cannot be excluded especially since the Seller had revealed the potential issue at the precontractual stage and the Buyer had experience and know-how on the bulletproof material market. ${ }^{111}$

108. See supra $\llbracket 2$, see infra $\llbracket 39$ (ii).

109. See infra $₫ 39$ (iii).

110. Judgment 4505/2009 at 14, 15, 93.

111. See Schwenzer, supra note 35, at 586-87 ("Could not have been aware" denotes more than gross negligence. Liability is only excluded for lack of conformity that is obvious [. . . ] However, the buyer has no obligation to examine the goods before the conclusion of the contract [...] The position will largely depend on the circumstances of the particular case, such as the nature of the goods, the skill and experience of each party, the reasonableness of an examination by the buyer, etc. If the seller combines the request to examine the goods with a reference to possible defects in the goods, then, in any event, the buyer loses its rights under Article 35(3) in respect of defects which would have been obvious upon such an examination, even if it does not perform it."). 
26. Furthermore even if one accepts that the Court only applied article 35, $\S 1$ CISG to examine the alleged lack of conformity the Buyer could still, on the basis of the above facts, had lost its right to rely on the alleged lack of conformity since, as it is suggested by legal doctrine, if the buyer knows from the beginning that the goods cannot be brought into compliance with the agreement under article $35, \S 1$ by the time of delivery, then any insistence on such compliance constitutes venire contra factum proprium (i.e. breach of a general principle of the article 7, $§ 2$ CISG) ${ }^{112}$ In addition it is suggested that article $35, \S 3$ CISG applies by way of analogy to situations falling within the scope of article $35, \S 1$ CISG. ${ }^{113}$ Finally it has been judged within the context of examining conformity of the goods to the contract under article $35, \S 1$ CISG that the buyer cannot complain about defects of which he either knew or could not have been unaware since a buyer who buys goods, despite their obvious defects, must be assumed to have accepted the goods as they are; ${ }^{114}$ it is noted this last result can also be achieved also by virtue of article $7, \S 1$ and/or 6 CISG since, in our opinion, such interpretation of article $35, \S 1$ obviously observes (and promotes) good faith in international trade and, at the same time, takes into consideration the buyers' implied agreement without recourse to article $35, \S 3$ CISG being necessary. Based on the above and the factual assumptions of the Court ${ }^{15}$ one cannot preclude that the Buyer could be deemed to have accepted the Bullet-Proof Material and thus could not rely on the alleged lack of conformity.

112. See Ingeborg Schwenzer, Commentary on the Un Convention on the International SALE OF Goods (CISG) 428 (Peter Schlechtriem \& Ingeborg Schwenzer eds., 2d ed. 2005). It is suggested that the principle of venire contra factum proprium stems from article 80 CISG. Kornilakis, supra note 45 , at 14 (This Author makes reference to a general principle pursuant to which the parties must show the behaviour of a reasonable man, CISG arts. $8, \S 2,25$, which also includes the prohibition of the abusive exercise of rights and in particular the venire contra factum proprium principle.). See also Rolled Metal Sheets Case (F.R.G. v. Austria) Internationales Schiedsgericht der Bundeskammer der gewerblichen Wirtschaft-Wien SCH-4813 (Vienna Arbitral Tribunal 1994) (Austria) (showing the venire contra factum proprium is definitely a principle governing the parties' behaviour in international commercial transactions which, although not expressly mentioned in the CISG, it stems from articles $29, \S 2$ and $16, \S 2$ CISG).

113. See Fritz Enderlein \& Dietrich Maskow, International Sales Law 147-48 (1992).

114. See René Franz Henschel, Conformity of Goods in International Sales Governed by CISG Article 35: Caveat Venditor, Caveat Emptor and Contract Law as Background Law as a Competing Set of Rules, 1 Nordic J. Com. L. (2004) (referencing: (i) Vaud Cantonal [Appellate Court] Switzerland, 28 Oct. 1997; and (ii) Sion Cantonal [Appellate Court] Switzerland, 29 June 1998).

115. See supra $\uparrow 25$. 
(ix) Article 40 CISG?

27. Finally it would be preferable if the Court, in the interests of completeness, had also considered whether article 39 CISG was not applicable in view of the possibility that the lack of conformity related to facts of which the Seller knew or could not have been unaware and which it did not disclose to the Buyer. ${ }^{116}$ In particular, within the context of the Buyer's Action, the Seller raised an objection that the Buyer's claim had already been prescribed. In order to rebut the Seller's objection on prescription, the Buyer raised a counter-objection ${ }^{117}$ and claimed that the Seller, being aware from its extended experience and know-how at the time the risk was transferred to it, that the Bullet-Proof Material failed in its antiballistic qualities with respect to the type of the bullet-proof vest which would be used, although it was obliged to notify to the Buyer the lack of agreed quality, it (the Seller) deliberately withheld it in order to undertake the supply. ${ }^{118}$ Furthermore it has to be noted that the Buyer based its claim against the Seller for pre-contractual liability of the latter on an argument similar to the above (i.e. that the Seller, although it was aware from its extended experience and know-how that the "behaviour" of the Bullet-Proof Material was differentiated according to the design of the Bullet-Proof Vests, it deliberately omitted to notify this to the Buyer and the State Weapon Co.); the Court however with a number of counter-arguments rejected in its substance the claim of the Buyer. ${ }^{119}$ On this basis it can be suggested that even if the same or similar argument was suggested by the Buyer within the context of article 40 CISG, the Court would most probably had rejected the Buyer's argument in its substance with similar arguments and accordingly article 40 CISG would not apply under the specific facts. ${ }^{120}$

116. See CISG art. 40. As a basic principle the buyer must, within the context of article $40 \mathrm{CISG}$, prove that the seller knew of the facts relating to the lack of conformity or could not have been unaware of them. If the buyer however can prove the lack of conformity resulted from the seller's sphere of responsibility, the burden of proof shifts onto the seller under consideration that it is closer to the facts: $c f$. SCHWENZER, supra note 35, at 647.

117. See supra note 170 .

118. See infra $₫ 42$.

119. See infra 9 १ 39 (i-iii).

120. Furthermore it is apparent that article 40 CISG will only apply in exceptional circumstances. See Oberster Gerichtshof [Supreme Court] Austria, 19 Dec. 2007, available at http://cisgw3.law.pace.edu/ cases/071219a3.html. See also Alejandro Garro, The Buyer's "Safety Valve" Under Article 40: What Is the Seller Supposed to Know and When?, 25 J.L. \& CoM. 253-60 (2005) (commenting on article 40 CISG). 


\section{(x) The Point of the Transfer of Risk}

28. From the text of Judgment $4505 / 2009$ it is apparent that the Court did not deal with the issue of the time when the risk was transferred and also that there was no special clause in the Bullet-Proof Material Sale Contract that regulated this issue, neither any clause according to which the Seller was obliged to send the Bullet-Proof Material to the Buyer by means of a carrier. Furthermore, it is obvious that the Bullet-Proof Material was not purchased while being transported. Therefore, articles 67 and 68 CISG do not apply. Nevertheless, it is stated in Judgment 4505/2009 that the Bullet-Proof Material would be delivered by the Seller in Athens, ${ }^{121}$ that is the Seller had undertaken the transport of the Bullet-Proof Material to Athens and that the Bullet-Proof Material Sale Contract had been concluded as a destination contract. On this basis, it can be said that the Buyer was obliged to take delivery of the BulletProof Material at a place (in Athens) other than the place of business of the Seller (the Netherlands). Consequently, the risk passed to the Buyer in accordance with article $69, \S 2$ CISG ("when delivery is due and the buyer is aware of the fact that the goods are placed at his disposal at that place"), i.e. once the Seller would place the quantities of Bullet-Proof Material available to the Buyer's disposal in Athens and inform the Buyer as to this event (even if the Buyer did not take over of the goods). ${ }^{122}$

\section{(xi) The Matter of the Burden of Proof}

29. As said, if the Buyer had observed the duties of articles 38 and 39 CISG (i.e. if it had inspected the Bullet-Proof Material within as short period as is practicable in the circumstances and had notified to the Seller the lack of conformity of the Bullet-Proof Material with the Bullet-Proof Material Sale Contract within a reasonable period of time), ${ }^{123}$ then, pursuant to Judgment $4505 / 2009$, it could have reversed the burden of proof and therefore the Seller would then have the burden to prove that the Bullet-Proof Material was in conformity with the Bullet-Proof Material Sale Contract at the time the risk

121. Judgment $4505 / 2009$ at 30 .

122. See Gunter Hager \& Martin Schmidt-Kessel, Commentary on the Un Convention on the International Sale of Goods (CISG) 939 (Peter Schlechtriem \& Ingeborg Schwenzer eds., 3d ed. 2010).

123. See supra $\uparrow \uparrow 18,19$. 
was transferred, i.e. at the time the Bullet-Proof Material was made available in Athens to the Buyer's disposal. ${ }^{124}$

\section{(5) Seller's Action: Buyer's Objection Relating to Set-Off}

30. The Buyer suggested for set-off, inter alia, its claim against the Seller for the amount of $€ 43,247.36$ as part of the expenses (total being $€ 655,671.01$ ) that the Buyer sustained in order to repair the delivered Bullet-Proof Vests and replace the Bullet-Proof Material with aramidic (Kevlar) material following request by the Authority. ${ }^{125}$ The Court, rightly in our opinion, judged that articles 440, 441 and 442 of the Greek Civil Code applied, ${ }^{126}$ since, in accordance with the article $7, \S 2$ CISG, there is an external gap in the CISG as to the question of set-off, which cannot be regulated by a general principle of the CISG and therefore it shall be regulated by the law to which the private international law of the forum refers to; consequently, according to the rules of the Greek private international law applicable at that time, Greek law was the applicable law according to the express choice of the parties by means of a relevant clause incorporated in the Bullet-Proof Material Sale Contract ${ }^{127}$ and therefore the question of set-off was regulated by the provisions of the Greek Civil Code. ${ }^{128}$ Since most of the counter-claims suggested by the Buyer for set-off (including remaining amounts on account of expenses for the repair of the Bullet-Proof Vests) were also part of the Buyer's Action against the

124. CISG art. 35, 36. See supra $\uparrow \uparrow 18,19,28$.

125. See supra $\uparrow 12$.

126. Under Greek law the conditions for unilateral set-off are: (i) reciprocity of claims, Astikos Kodikas [A.K.] [Civil Code] Article 440 (Greece) [hereinafter GCC]; (ii) claims must be of the same kind, GCC art. 440; (iii) claims must be due, GCC art. 440; and (iv) set-off must be permitted, GCC arts. 450, 451. The extinction of reciprocal claims by set-off does not come about ipso jure, simply by the fulfilment of the four conditions above. For the occurrence of the effects of extinction, it is required that set-off should be exercised by one of the parties by declaration to the other. GCC art. 441 I 1 . See Michael Stathopoulos, Contract Law in Greece 161-62 (2d ed. 2009).

127. CISG arts. $3, \S 1,10$. See supra $₫ 15$.

128. Judgment $4505 / 2009$ at 11 . On the opinion that set-off is not within the scope of the CISG, see Monomeles Protodikeio [Single Member Court of First Instance of Thessaloniki] Greece, 2008, available at http://cisgw3.law.pace.edu/cases/080002gr.html (Dionysios Flambouras, Editorial Remarks); Oberlandesgericht [Appellate Court of Köln] Germany, 19 May 2008, available at http://cisgw3.law .pace.edu/cases/080519g1.html; Appellationsgericht [Appellate Court of Basel-Stadt] Switzerland, 26 Sept. 2008, available at http://cisgw3.law.pace.edu/cases/080926s1.html; Landgericht [First Instance Court of Bamberg] Germany, 23 Oct. 2006, available at http://cisgw3.law.pace.edu/cases/061023g1.html; Huber, supra note 45, at 234. On the opinion that set-off is within the scope of the CISG, see SCHWENZER, supra note 35 , at 87 (These Authors support the minority opinion that is based on the rules in articles $81, \S 2,84$, $\S 2$ and 88 , $\S 3$ CISG the concept of set-off is generally encompassed by the CISG with regard to claims based on the CISG.). 
Seller which was filed by the Seller prior to the pleading of the set-off objection, the Court suspended its judgment on these counter-claims until a definite judgment on the Buyer's Action was issued. ${ }^{129}$

\section{Sellers' Action Was Accepted by the Court in Substance}

(1) Unsettled Invoices Corresponding to Instalments No. 7, 9 and 10-Buyer's Refusal to Take Delivery of the 11th Instalment and Refusal to Pay the Price

31. The Court finally judged and accepted that the following were proved:

(i) Due to the contractual breach of the Buyer (since the Bullet-Proof Material conformed to the Bullet-Proof Material Sale Contract) ${ }^{130}$ the Seller suffered positive damage (thetiki zimia) equal to $€ 438,771.58$, i.e. the total of the unsettled invoices, ${ }^{131}$ which were due with all legal interest thereupon from the day following the day they were agreed to be settled (due payment date).

(ii) The Seller suffered loss of profit (apothetiki zimia) equal to $€ 290,856.22$. This was due to fact that the Buyer was not entitled to declare the 11th instalment (shipment) of $29.871 \mathrm{~lm}$ of Bullet-Proof Material avoided, ${ }^{132}$ since the Seller had fully met the requirements of the Bullet-Proof Material Sale Contract (i.e. there was no lack of conformity of the Bullet-Proof Material with the requirements of the Bullet-Proof Material Sale Contract at the time the risk was transferred $^{133}$ and the actual reason for which the Buyer declared the 11th instalment avoided consisted in the fact that this quantity was not actually necessary to it. ${ }^{134}$ On this basis, since the Buyer was not entitled to declare the 11th instalment avoided, no party was released from its contractual obligations and the value $(€ 290,856.22)$ of the 11th instalment of Bullet-Proof Material was due to the Seller, which (quantity of Bullet-Proof Material) was duly prepared and offered by the Seller, without however the Seller's obligation being performed due to the Buyer's fault (who refused to take delivery of the last

129. See infra $₫ 33$.

130. See infra $₫ 48$

131. See supra $\uparrow \uparrow 11,12,13,22(\mathrm{a})$.

132. See supra $\uparrow 9,22(\mathrm{~b})$.

133. CISG arts. 35, 36. See supra $₫ 28$, see infra $₫ 48$.

134. See supra $₫ 22(\mathrm{~b})$. 
quantity of Bullet-Proof Material). Consequently the amount of $€ 290,856.22$ was due with legal interest thereupon from the day following the extrajudicial notice to the Buyer by the Seller which was served on 26.9.2002.

Furthermore, the court adjudicated the Buyer to pay the above under (i) and (ii) amounts with legal interest from the relevant dates. ${ }^{135}$ The reference of the text of Judgment 4505/2009 to "positive damage" and "loss of profit" leads to the conclusion that the Court adjudicated the Seller the price corresponding to instalments no. 7, 9 and 10 (of which the Buyer had taken delivery) and instalment no. 11 (of which the Buyer did not take delivery), based on the provisions for damages that is recovery of the loss that the Seller suffered due to the fact that the Buyer breached its contractual obligation to pay the price. ${ }^{136}$ It is however suggested that payment of the price could also be legally based only on articles 53, 61 and 62 CISG from which a relevant self-existent claim for the payment of the agreed purchase price derives. ${ }^{137}$

135. The Court supported this decision by stating that: "From CISG Article 78, it is concluded that interest is due, without it being necessary to serve a notice upon the promisor and regardless of any damage sustained by the promisee." Judgement 4505/2009 (for the relevant part of the legal reasoning of Judgment 4505/2009 see Dionysios Flambouras, Editorial Remarks to Judgment 4505/2009, § 2.2.12, available at http://cisgw3.law.pace.edu/cases/094505gr.html; see also Polymeles Protodekeo [Multi Member First Instance Court of Thessalonica] Greece, 2003, available at $\mathrm{http}$ //cisgw3.law.pace.edu/cases/030513gr.html (Dionysios Flambouras, Editorial Remarks); Monomeles Protodekeo [Single Member First Instance Court of Thessalonica] Greece, 2003, available at [http://cisgw3.law.pace.edu/cases/030001gr.html (Dionysios Flambouras, Editorial Remarks).

136. See CISG arts. $61,74,77$.

137. Under the CISG, the Seller can require the buyer to pay the purchase price and for such an action the purchase price must be fixed or determinable and due. CISG arts. 28, 61, § 1(a), 62. See Florian Mohs, Comment ary on the UN Convention on the International SAle OF Goods (CISG) 879 (Peter Schlechtriem \& Ingeborg Schwenzer eds., 3d ed. 2010). In connection to instalments no. 7, 9 and 10 invoices had been issued and it was very clear that the Seller could request payment of the price since the due dates had passed. Instalment no. 11, see supra $₫ 9$, had been prepared and offered by the Seller to the Buyer and since it conformed to the Bullet-Proof Material Sale Contract at the time of transfer of risk, the Buyer, as of the time that instalment no. 11 was made available to it, was obliged to pay for its corresponding price. See CISG arts. 31, 58, § 1, 67, 69; Judgment 4505/2009, translated in Dionysios Flambouras, Editorial Remarks to Judgment 4505/2009, § 2.2.13, available at http://cisgw3.law.pace.edu/ cases/094505gr.html. 


\section{Buyer's Action-Legal Issues and Substance-Court's JUDGMENT-COMMENTARY}

\section{A. Buyer's Action}

32. The Buyer filed an action against the Seller and requested from the latter to pay:

(i) The amount of $€ 612,423.655$ as positive loss ("thetiki zimia") and loss of profit ("apothetiki zimia") which it suffered because the Bullet-Proof Material that the Seller delivered to it (i.e. including the six instalments that the Buyer had already purchased and for which it had already paid the price) ${ }^{138}$ was not in conformity as per quality and kind with the requirements of the Bullet-Proof Material Sale Contract, and thus the Ministry (1) refused to take delivery of the remaining quantity of Bullet-Proof Vests that had been manufactured by the specific Bullet-Proof Material (under the Bullet-Proof Vests Manufacturing Contract); and (2) demanded from the Buyer to repair the already delivered Bullet-Proof Vests (by replacing the BulletProof Material with aramidic material). ${ }^{139}$

(ii) The amount of $€ 8,151.08$ which corresponded to the price for the sale of 3,189 kg net weight of pieces of Bullet-Proof Material which were left over to the Buyer from the processing (i.e. for the manufacturing of the Bullet-Proof Vests) of the Bullet-Proof Material that the Seller had dispatched, since the Seller had accepted the Buyer's offer to purchase these pieces against $5 \mathrm{DM}$ or $€ 2.56 / \mathrm{kgr}^{140}$

(iii) The amount of $€ 7,670.87$ which corresponded to the Seller's share in the expenses of the ballistic tests that were conducted in the ballistic centre of G. University in the U.K. (a claim assigned to the Buyer by the State Weapon Co.). ${ }^{141}$

(iv) The amount of $€ 300,000$ as compensation for moral damages sustained by the Buyer due to the fact that its reputation was damaged, since, by reason of the counter-contractual behaviour of the Seller, the Buyer's commercial relations with its main and

138. See supra $₫ 6$.

139. See supra ๆ $11,12$.

140. See infra $₫ 46$.

141. See supra $\llbracket 2$, see infra $\llbracket 47$. 
privileged clients, i.e. the Ministry and the Authority, were disturbed and the validity and credibility of its goods to them were damaged. ${ }^{142}$ As regards the above claims, the Buyer invoked the provisions on sale, precontractual liability, tort and, as a subsidiary claim, unjustified enrichment.

\section{B. Judgment of the Court on Buyer's Action}

\section{(1) Applicable Provisions}

33. The court judged that the Buyer's action, to the part that was based on the Bullet-Proof Material Sale Contract was legally grounded, based on articles $1, \S 1(a), 3,4,6,7,9,14,15,18,23,25,30,31,33,35,36,38,39,45$, $53,57,58,59,61,62,66,67,74,78,99$ and 100 CISG. $^{143}$

(2) Buyer's Claim Based on CISG for Compensation Regarding Lack of Conformity of Instalments

34. The compensation claim of the Buyer sought to recover the damage that the Buyer suffered due to the lack of conformity of the Bullet-Proof Material with the Bullet-Proof Material Sale Contract, including the quantities of Bullet-Proof Material delivered under the six instalments which, as is apparent, the Buyer had not declared avoided since it had already used the delivered quantities under those six instalments in order to manufacture 6,900 Bullet-Proof Vests. ${ }^{144}$ This compensation claim is indeed, as the Court judged, based on articles $45 \S 1(\mathrm{~b})$ and 74-77 CISG since, in a sales contract with instalments, as regards the case of breach of an instalment (or instalments), apart from the fact that a party is entitled to declare such instalment(s) avoided in case of a fundamental breach, ${ }^{145}$ the non-breaching party is entitled, in respect to such instalment(s), to all legal remedies in force for the sale contract as a whole and consequently is entitled to the right to claim damages either concurrently with avoidance or even if it has not declared the contract avoided. ${ }^{146}$ The Court practically rejected on substantial grounds the Buyer's

142. See infra $₫ 40$.

143. The legal part of Judgment $4505 / 2009$ includes numerous recitals of principles of law together with extensive references to, mainly, Greek legal doctrine and case law. Judgment 4505/2009, translated in Dionysios Flambouras, Editorial Remarks to Judgment 4505/2009, §§ 2.1-2.4.1, 3, available at http:// cisgw3.law.pace.edu/cases/094505gr.html.

144. See supra $\uparrow \uparrow 6,11,12$.

145. CISG art. $73, \S 1$.

146. See supra note 73. Cf. Fountoulakis, supra note 55, at 985 ("Instead of avoiding the contract 
Action to the extent that it was legally based on the CISG provisions for compensation. ${ }^{147}$

\author{
(3) Monetary Claim of the Buyer Based on the Provisions on Tort and \\ Unjustified Enrichment-Court's Judgment on Legal Issues: Concurrent \\ Remedies
}

35. In connection with its above claims the Buyer also invoked the
domestic Greek provisions on tort (adekopraxia) $)^{148}$ and, as a subsidiary claim,
the provisions of unjustified enrichment (adekeologetos ploutesmos). ${ }^{149}$ On

with regard to the defective statement, the creditor might wish to exercise other remedies available under the CISG, such as the right to claim performance, substitute delivery, cure of the defect, a reduction of the price or a right of suspension"). Furthermore even if the Buyer had declared these instalments avoided it would still be entitled to also demand full damages for the Seller's failure to perform with regard to all losses (e.g. costs for removal of a non-conforming item or substitute sale, compensation for damages due to delay and to ancillary and consequential losses). CISG arts. $45, \S 2,75,76,81, \S 1$. See MüLlER-ChEn, supra note 107, at 699-700 (This Author further states that in order for a buyer to be able to avoid the sale contract (or one or more instalments under an instalment contract), the buyer is obliged to satisfy the limitation set forth in article 49 CISG, particularly the timely declaration of the contract, see CISG art. 49, $\S 2$ and see supra $\lceil 24$; if these preconditions have not been satisfied, the buyer is obliged to allow the seller to keep the price or to pay the price (offset in certain circumstances against its (buyer's) claim for damages).).

147. See infra $₫ 48$.

148. GCC art. 914. In Greece there is a general clause on tortious liability, it being article 914 GCC which provides as follows: "A person who unlawfully and by its fault has caused prejudice to another shall be liable for compensation." On this basis if: (i) there is an act which is unlawful and due to fault (culpa) (civil delict); (ii) such act is causing prejudice (injury, detriment, damage); and (iii) there is casual relation between this act and the prejudice, then the party responsible is obliged to compensate. As regards concurrence of contractual and tortious liability under Greek law the following should be noted: when the act or omission which constitutes the contractual non-performance is simultaneously and itself unlawful (i.e., it would also have been unlawful if it had been committed without the pre-existent contract), concurrence of the two liabilities, tortious and contractual, is accepted. Only to the extent that the act of non-performance of the obligation would not have been, without the pre-existent contract, unlawful, the implementation of the tortious liability is precluded, by reason of the special nature of the provisions on contractual liability (i.e. the injured party cannot choose between the provisions on contractual and those on tortious liability depending on which best serve its interests) (French principe de 'non-cumul'). See Stathopoulos, supra note 126 , at $42,44,45$.

149. GCC art. 904. The institution of unjustified enrichment (adekeologetos ploutesmos) is regulated by articles 904-913 GCC. art. 904, § 1 sub-paragraph 1 GCC provides "A person enriched without a lawful cause from the patrimonium or to the detriment of another person is obliged to restitute the benefit." On this basis for the generation of unjustified enrichment the following conditions have to be met: (i) there should be enrichment of a person, that is, of the debtor (who is obliged to return the enrichment); (ii) the enrichment should have come about "from the patrimonium or to the detriment" of the creditor (who is obliged to return the enrichment); (iii) the enrichment should be unjustified ("without just cause") (i.e. cause of the retention of the enrichment); and (iv) there should be a casual relation between the enrichment of the debtor and the impoverishment of the creditor. The claim arising from unjustified enrichment stems 
this basis the Buyer brought into the picture the situation when a domestic law provides legal consequences for the very same operative facts that invoke the rules of the CISG, when the rule of domestic law bears label other than "contract"; in this instance the question is whether such a domestic rule remains in effect as an alternative to the provisions of the CISG (concurrent remedy). ${ }^{150}$ The Court, correctly in our opinion, rejected as non-legally based, the grounds for the Buyer's action for tort and unjustified enrichment, judging that they do not concurrently apply with the provisions of the CISG since otherwise there is a risk for non-uniform application of the CISG and therefore the Buyer could only claim under the CISG compensation for the damages it sustained. ${ }^{151}$

36. The Court, in particular, held that if there is concurrent application of domestic provisions for tort (non-contractual liability) with the provisions of the CISG (contractual liability), the party that suffered damage (due to breach of contract)] may claim compensation for its material damage only based on the provisions of the CISG, otherwise there is the risk for non-uniform application of the CISG. ${ }^{152}$ The question whether, in contracts governed by the

directly from the law (ex lege) and is self-existent as regards contractual obligations (which stem from private autonomy), even though the enrichment was brought about by a contract and became unjust and returnable afterwards because the contract, for example, was overturned. Furthermore, the prevailing view in Greece suggests that the claim for unjust enrichment is subsidiary, which means that it is granted to the claimant by the law only if it does not have any other claim for its satisfaction (however there is also support for the view that, if the conditions of other provisions are fulfilled, there will be concurrence of these provisions with that on unjust enrichment). See Stathopoulos, supra note 126, at 243-52.

150. HonNOLD, supra note 84, at 63-64.

151. See supra $₫ 32$.

152. See Anastássios Valtoudis, To Próblema tes Sirroés tes Efthýnes jiá Pragmatiká Elattómata Katá te Sýmbasi tes Wiénes (CISG) me to Ethnikó Exosymbatikó Díkaio [The Problem with Concurrent Liability for Defects pursuant to the Vienna Convention (CISG) compared with the domestic noncontractual law], Armenopoulos: Thessaloniki 327, 348 (1999); PANAYiotis Kornilakis, Contract Law-Particular Contracts 113; Georgios Nikolaides, The International Sale of Goods under the CISG, The Int'L Sale 64 (2000); Dionysios Flambouras, International Sales, Int'L Transactions L. 682-83 (Pamboukis ed., 2009); Ingeborg Schwenzer \& Pascal Hachem, The CISG-Successes and Pitfalls, 57 Am. J. Comp. L. 457, 470-71 (2009); Ingeborg Schwenzer \& Pascal Hachem, Commentary on the UN Convention on the International Sale of Goods (CISG) 100-01 (Peter Schlechtriem \& Ingeborg Schwenzer eds., $3 \mathrm{~d}$ ed. 2010) (These authors suggest the following distinction: if the property (i.e. material) damage is the typical result of the breach of contract, i.e. the non-conformity of the goods, then the CISG is considered to be exclusive, whereas if the property (material) damage is the result of the breach of standard safety expectations then concurring claims under domestic law are admissible (since the CISG is not concerned with general duties of safety).). Peter Schlecthriem, The Borderland of Tort and Contract-Opening a New Frontier?, 21 CoRNELL InT'L L.J. 467 (1988) (If a domestic court law protects the expectations of a buyer with regard to the quality of goods and thereby concurs with matters genuinely governed by CISG, it is sufficient to adjust the 'concurring' tort action to the rules of CISG. It could not be maintained, if the notice requirement was neglected [. . . However, the injured parties could still sue in 


\section{CISG, domestic law provisions on torts can apply concurrently with the CISG is a matter of great controversy and as it is well known there is also strong support for the opinion that such concurrent application is to a greater or lesser extent possible. ${ }^{153}$}

tort in a forum having jurisdiction only for tort actions, for jurisdiction and venue are not matters governed exclusively by CISG. The same would apply to other features of tort actions outside the scope of the CISG.); HonNOLD, supra note 84, at 74,76 ("Domestic rules that turn on substantially the same facts as the rule of the Convention must be displaced by the Convention; any other result would destroy the Convention's basic function to establish uniform rules (Art. 7(1)). [ . . . ] Permitting recourse to domestic law can be unfair since not all domestic systems permit choice between contract law ('non-cumul')."). See Electrocraft Ark., Inc. v. Elec. Motors, Ltd et al., 2009 WL 5181854 (E.D. Ark. Dec. 23, 2009), available at http:// cisgw3.law.pace.edu/cases/091223u1.html ("[T]here is agreement that concurring state contractual claims are preempted by the CISG [. . .] Thus, a tort that is in essence a contract claim and does not involve interests existing independently of contractual obligations (such as goods that causing body injury) will fall within the scope of the CISG regardless of the label given to the claim [...] and therefore not require a determination concerning the preemptive effect of the CISG on tort remedies.); Forestal Guarani, S.A. v. Daros Int'1, Inc., 2008 WL 4560701, (D.N.J. Oct. 8, 2008), available at http://cisgw3.law.pace.edu/ cases/081007u1.html ("the CISG ... preempts state contract law and common law, to the extent that those causes of action fall within the scope of the CISG ...”); Geneva Pharm. Tech. Corp. v. Barr Labs, Inc., 201 F. Supp. 2d 236, 291 (S.D.N.Y. 2002), available at http://cisgw3.law.pace.edu/cases/020510u1.html (It was held by the Court that the buyer's negligence-based (domestic law) claims were preempted by the CISG, whereas the buyer's business tort claims for tortious interference with contract and business relations were not.); see also Joseph Lookofsky, CISG Case Commentary on Preemption in Geneva Pharmaceuticals and Stawski, Pace Rev. Convention on Cont. for the Int'L Sale of Goods 115, 119 (2004); Oberlandesgericht Thüringen [Court of Appeal of Thüringen] Germany, 26 May 1998, available at http://cisgw3.law.pace.edu/cases/980526g1.html ("Lack of sufficient notice within the scope of the CISG also extends to exclude other concurrent remedies, such as a claim for tortious liability.").

153. Franco Ferrari, The Interaction Between the UNConventions on Contracts for the International Sale of Goods and Domestic Remedies, 71 Rabels ZeItschrift FÜr AusLÄndisches und InTERNATIONALES PRIVATRECHT 52, 75-76 (2007) (It is initially stated that "to the extent that the protected interests overlap (as is the case where the purchased goods are damaged), the CISG applies exclusively and trumps domestic law" but eventually suggested that "a tort action for property damages caused by defective and non-conforming goods should not be barred by an omission to give notice within reasonable time under Art. 39 CISG."); Joseph Lookofsky, In Dubio Pro Conventione? Some Thoughts About Opt-Outs, Computer Programs, and Preemption Under the 1980 Vienna Sales Convention (CISG), 13 DuKE J. ComP. \& INT'L L. 263, 286 (2003); Huber, supra note 45, at 233. As to case law supporting this view, see Ceramica v. Mendelson Eng'g Technical Supply Ltd, Supreme Court, Israel, 17 Mar. 2009, available at http://cisgw3.law.pace.edu/cases/090317i5.html (The Court allowed the buyer to make its claim in tort that the seller was negligent in the manufacture of the tiles sold since, in the Court's opinion, the interests which the buyer was "struggling" to protect were not identical to the interest which the uniform law of the CISG seeks to protect.). See Joseph Lookofsky, CISG Case Commentary on Concurrent Remedies in Pamesa v. Mendelson, PACE L. SCH. InST. InT'L COM. L. (2010), available at http://ww.cisg.law.pace.edu/ cisg/biblio/lookofsky19.html); Shane v. JCB Belgium N.V., [2003] Superior Court of Justice, available at $\mathrm{http} / / /$ cisgw3.law.pace.edu/cases/031114c4.html (Can.) ("The plaintiffs are claiming damages for negligent manufacture and design of the tractor [. . . The law which the parties agree applies [to the contract] is the CISG [... ] A greater factor is the law where the tort occurred should be applied for claims in negligence"); Viva Vino Imp. Corp. v. Farnese Vini, 2000 WL 1224903 (E.D. Pa. 2000), available at http://cisgw3.law.pace.edu/cases/000829u1.html ("The CISG does not apply to tort claims. Consequently, 
37. Furthermore the Court held that if the provisions of the CISG apply concurrently with the domestic provisions on unjustified enrichment the application of the domestic provisions is excluded since, on the one hand, the provision of article $84, \S 2$ CISG is the basis for the relevant general principle of the Vienna Convention which orders the return of the enrichment received in case the sales contract is declared avoided at a later time, ${ }^{154}$ and on the other hand, the provision of article $81, \S 2$ (a) CISG provides that after the exercise of a party's remedy to declare the contract avoided, there is an obligation by law (ex lege) for the return (restitution) of the obligations that have been performed. ${ }^{155}$ The opposite opinion is however also supported, i.e. that, as

it is inapplicable to plaintiff's claim of tortious interference with business relations."); Roder v. Rosedown (1995), available at $\mathrm{http} / / / \mathrm{cisgw} 3$.law.pace.edu/cases/950428a2.html (Austl.) (A claim against the buyer and the administer based on "the tort of conversion for interfering with the possessory rights of [seller]" was regarded as outside the scope of the CISG and ruled on by the Court under domestic law.). Beijing Metals \& Minerals Import/Export Co. v. American Business Ctr., Inc., 993 F.2d 1178, 1183 n.9 (5th Cir. 1993), available at $\mathrm{http}: / / \mathrm{cisgw} 3$. law.pace.edu/cases/930615u1.html (The Court referred solely to Texas law in its evaluation of allegations of actionable fraud and economic duress.).

154. See Robert Hilman, Applying the UN Convention on Contracts for the International Sale of Goods: The Elusive Goal of Uniformity, Cornell Rev. Convention for the Int'L Sale of Goods 21, 35-37 (1995), available at http://www.cisg.law.pace.edu/cisg/biblio/hillman1.html; SCHwENZER, supra note 35 , at 139 ("Article 84 is understood to establish a general principle requiring restitution of unjustified enrichments gained by a failed sales transaction").

155. See Nikolaides, supra note 152, at 136; Georgios Nikolaides, Sphere of Application of the Vienna Convention for the International Sale of Goods 258 (2001). Flambouras, supra note 152, $\S 684$; FoUNTOULAKIS, supra note 55, at 1103 ("The decisive question is whether the rules of restitution of the CISG can be supplemented or even replaced by national restitutionary law. The answer is clearly in the negative. The most obvious reason for this can be found in Article 7(1), viz, in the requirement to promote uniformity when applying the CISG [...] the whole liquidation of the contract is subjected to a uniform, autonomously regulated regime that grants (only) contractual claims for restitution. The need for a uniform application of the CISG is only satisfied if domestic laws - be it legal provisions on contract, unjust enrichment, or property rights-are excluded.); CISG-AC Opinion No. 9, Consequences of Avoidance of the Contract, Rapporteur: Professor Michael Bridge, LSE, London, U.K., Adopted by the CISG-AC in its 12th meeting in Tokyo, Japan on 15.11.2008, Opinion 1.5, Comment 3.8 et seq.; Magnus, supra note 69, at 431; Henry Deeb Gabriel, The Buyer's Performance Under the CISG: Articles 53-60 Trends in the Decisions, 25 J.L. \& CoM. 273, 279 (2005) ("Since the CISG governs questions of avoidance and restitution, an agreement otherwise governed by the CISG would appear to require that the initial inquiry should be based on the rules and principles of the CISG. Only if it is determined that the CISG does not answer the question should one fall back on other law."). On case law supporting this view, see 1999 Int'l Comm. Arb. No. 9978, available at http://www.unilex.info/case.cfm?pid=1\&do=case\&id=471\&step $=$ FullText ("In the oral hearing, Respondent has argued that it is relieved from refunding the purchase price to Claimant because the monies received from Claimant are no longer in Respondent's possession. This view, however, misinterprets the true nature of the restitution system established in Art. 81 et seq. CISG. This system does not establish a condictio indebiti in the proper sense. For this reason, a reference to the rules of unjust enrichment of the applicable domestic law is neither necessary nor permissible [. . . ] $[R]$ ather, the system is based on the Roman law model of actio quanti minoris."); Handelsgericht [Commercial Court of Zürich] Switzerland, 5 Feb. 1997, available at http://cisgw3.law.pace.edu/cases/ 


\section{regards contracts governed by the CISG, domestic provisions on unjustified enrichment can apply concurrently with the CISG. ${ }^{156}$}

970205s1.html ("Upon contract avoidance and a thereby following duty of the seller is to refund the purchase price received beforehand or parts thereof, the seller has to pay interest on it from the date on which the price was paid (CISG Art. 84(1)").

156. Ana M. López Rodríguez, The Effects of Avoidance on Obligations: The Modes of Restitution under the 1980 U.N. Convention on the International Sale of Goods, 9 VindoBona J. COM. L. \& ARB. 291, 298 (2005) ("[A] cautious approach would refer this matter to the applicable domestic law."). On case law supporting this view, see Miami Valley Paper, LLC v. Lebbing Eng'g \& Consulting GmbH, 2006 WL 2924779 (S.D. Ohio Oct. 10, 2006), available at http://cisgw3.law.pace.edu/cases/061010u1.html (In a proceeding governed by the CISG, the Court cites U.S. domestic law in support of the proposition that "there is conflicting authority in this district as to whether a plaintiff may plead unjust enrichment as an alternative theory of recovery" and, also citing U.S. domestic case law, concludes that "a plaintiff may set forth both causes of action as alternative theories, pursuant to Fed. R. Civ. P. 8(c)(2). United States v. Boeing Co., 184 F.R.D. 107, 112 (S.D. Ohio 1998).”); Bundesgericht [Supreme Court] Switzerland, 7 July 2004, available at http://cisgw3.law.pace.edu/cases/040707s1.html ("Claims [for unjust enrichment] do not fall within the scope of the CISG ... The applicable provisions of international private law define which national law shall govern [claims] for undue enrichment."). Oberster Cerichtshof [Supreme Court] Austria, 10 Mar. 1998, available at http:cisgw3.law.pace.edu/cases/980310a3.html (“According to § 46(2) of the Austrian Statute regulating the Conflict of Private Laws as the private law provision of the forum, claims for restitution due to avoidance of contract are governed by the national law which is applicable to the contract itself [...] As the applicable CISG does not provide for restitutionary matters of the kind at issue, the claim is governed by Swiss law ..."). Cour d'appel [Appellate Court of Paris] France, 14 Jan. 1998, available at http://cisgw3.law.pace.edu/cases/980114f1.html (The Court considered, pursuant to art. 7 CISG, whether the question of the place of restitution of the price by the seller following cancellation of the sale could be settled in accordance with the general principles); Oberlandesgericht [Appellate Court of Linz] Austria, 8 Sept. 1997, available at http://cisgw3.law.pace.edu/cases/970908a3.html (With respect to the restitution of the deposit in question, the Court clarified that the restitution of a deposit is an obligation arising from an unjustified enrichment, which is a matter not covered by CISG.); 1990 Int'l Comm. Arb. No. 6149, available at http://cisgw3.law.pace.edu/cases/906149i1.html ("There are no provisions in the Vienna Convention covering claims for the restitution of an unjust enrichment or the limitation of claims. In order to be able to decide on these issues, the arbitral tribunal therefore would have to recur to the determination, by another rule of conflict of laws, of a national law as the proper law of contract and the arbitral tribunal would have to apply insofar such national law to the subject-matter of the present arbitration."); Adras Chmorey Binyan v. Harlow \& Jones GmbH, Supreme Court, Israel, 2 Nov. 1999, available at http://cisgw3.law.pace.edu/cases/881102i5.html (editorial remarks by Arie Reich, Daniel Friedman). See also Peter Schlecthriem, Uniform Sales Law-The Experience with Uniform Sales Law in the Federal Republic of Germany, 3 JURIDISK TIDSKRIFT 1, 12-13 (1991) (summarizing as follows: "An Israeli buyer had bought steel from a German seller. The contract was improperly performed. The buyer, however, had lost its remedies under ULIS by lapse of time and lack of notice, and it had lost a litigation in which the courts up to the Israeli Supreme Court applied the Hague Uniform Sales Law. Then the [buyer] started a new litigation saying in nuce that the German seller, by not performing the contract and not being liable under ULIS, was unjustly enriched. The buyer succeeded in claiming benefits which the German party allegedly had derived from not performing the contract under unjust enrichment rules. In this instance, the rules of the Convention and its requirement for certain remedies were pushed aside by a restitutionary remedy under domestic law."). 
(4) Buyer's Action: Buyer's Claim Based on Provision for Pre-Contractual Liability (Liability Under the Negotiations)_Court's Judgment on Legal Issues and Substance

38. Greek law imposes certain duties on parties who enter into negotiations, even before the action contract is concluded. ${ }^{157}$ The Buyer invoked pre-contractual liability of the Seller. As is it known, if the negotiations lead to a contract of sale that is governed by the CISG, the question will arise of whether domestic law provisions on pre-contractual liability can be invoked by the injured party or whether this is excluded by the CISG. ${ }^{158}$ In connection with this question (i.e. pre-contractual liability of the Seller as invoked by the Buyer), the court did not apply the CISG, but instead the provisions of the Greek Civil Code (articles 197 and 198) having judged, correctly in our opinion, that the issue of pre-contractual (i.e. established during the negotiations) liability is not regulated by the CISG, except for the cases in which the CISG regulates specifically an issue for the period before the conclusion of the contract; ${ }^{159}$ therefore any remedy related to precontractual liability which derives from the provisions of domestic law to which the rules of private international law of the forum refer to, may apply in parallel with the provisions of the CISG, since the regulation of precontractual liability as a whole was excluded in the CISG intentionally by the international legislators. ${ }^{160}$ As is it is known there are opposite opinions which

157. Under Greek law the conditions for pre-contractual liability are the following: (i) stage of negotiations for the conclusion of the contract; (ii) conduct in bad faith (i.e. violation of the principles of objective good faith and common usage); (iii) fault of the party (wilful or negligent conduct) (culpa in contrahendo); and (iv) causing prejudice to the other negotiator (this prejudice must be in a casual relationship with the conduct which is due to bad faith and to fault). GCC art. 197. If the above conditions are fulfilled then the liability of the negotiator who has acted in bad faith and through its fault consists in an obligation to compensate the other party. GCC art. 198, § 1 . The compensation will not be the "positive interest" or "(non-) performance damages" owed in the case of contractual liability, but the "negative interest" or "damages suffered due to reliance on the conduct of the other party" (e.g., on the validity of its declaration, on the honesty of its conduct, etc.). See Stathopoulos, supra note 126, at 79-82.

158. Huber, supra note 45, at 234.

159. CISG art. $16, \S 2$.

160. Judgment $4505 / 2009$ at 20. See Valtoudis, supra note 35, at 47, 50; Flambouras, supra note 152 , at $\S \S 676-678$; see also Ulrich G. Schroeter, Commentary on the UN Convention on the InTERnAtional SALE of Goods (CISG) 247-48 (Peter Schlechtriem \& Ingeborg Schwenzer eds., 3d ed. 2010) ("The drafters of the Convention therefore expressly decided against the inclusion of pre-contractual duties within the scope of the Convention and the matters to which it relates. Against this background, the existence, scope, and content of pre-contractual duties as well as rules about any liability arising from their breach (e.g., culpa in contrahendo) are in principle governed by the domestic law invoked under the 
to a greater or lesser extent suggest that the issue of pre-contractual liability is within the scope of the CISG. ${ }^{161}$

39. The Court, expressing a series of arguments rejected as groundless in substance the Buyer's claim as to its base on pre-contractual liability (where articles 197 and 198 GCC were applied ${ }^{162}$ under which indemnification was claimed for the damage sustained by the Buyer due to the conclusion of the Bullet-Proof Material Sale Contract. The Buyer in particular claimed that the Seller at the stage of negotiations breached the principles of good faith and transactional morals (enlightening and protecting the other party); this was due to the fact that the Seller, although it was aware from its extended experience and know-how that the "behaviour" of the Bullet-Proof Material was differentiated according to the design of the Bullet-Proof Vests, it deliberately omitted to notify this to the Buyer and the State Weapon Co. The Court however judged that the Seller at the time of its participation in the international tender and also at the time of conclusion of the Bullet-Proof Material Sale Contract, did not deliberately omit to notify the existence of the above differentiation, since such conclusion would presuppose that the BulletProof Material did not operate properly in the specific design of the Bullet-

applicable conflict of laws rules [. . .] Breaking off negotiations and preventing the formation of contract should not trigger domestic law remedies, unless done so fraudulently. As the withdrawability and revocability of offers under Articles 15(2), 16(1) and the right to object or protest under Articles 19(2), 21(2) show, these are matters governed by the Convention, and the respective acts do not trigger liability, either for loss incurred or claims for the benefit of the expected bargain."); Huber, supra note 45, at 234 ("[A]s the CISG does not provide a regime for the breach of precontractual duties, those domestic rules should in principle be applicable irrespective of the fact that the contract underlies the CISG [...] there may be exceptions to that principle: In particular, if the seller has (innocently) induced the buyer to conclude the contract by not (correctly) informing him about certain defects of the goods and if applicable domestic law sanctions this behaviour as breach of a precontractual duty, there are good arguments for letting the CISG prevail over the domestic law.").

161. See supra note 160. Silvia Gil-Walin, Liability Under Pre-contractual Agreements and their Application Under Colombian Law and the CISG, Nordic J. Com. L. 1, § IIIA (2007) ("[. . .] the precontractual liability is within the scope of the CISG . . . if a court has to decide a case on pre-contractual liability the first step for the court is to look at the general principles that inspired the CISG because it constitutes an unsettled matter. Thus the interpretation and regulation of the pre-contractual liability will be possible through its principles. Consequently, there is no need to refer and resolve the case according to the private international law."); Diane Madeline Goderre, International Negotiations Gone Sour: Precontractual Liability Under the UN Sales Convention, 66 U. CIN. L. REv. 257, 280 (1997) ("Regardless of the apparent obstacles concerning the good-faith provision of Article 7, precontractual liability can nonetheless be imposed under the Convention"); Georgios Nikolaides, The Importance of Good Faith and Pre-contractual Liability Pursuant to the Vienna Convention for the International Sale of Goods, CHRON. Private L. 891 (2002) (It is suggested that the CISG applies also for pre-contractual liability pursuant to article 7, $\$ 2$ CISG which on the basis of a general principle orders good faith conduct during negotiations).

162. See supra $\llbracket 35$. 
Proof Vest that the Buyer manufactured, a fact which, however, had not been proved. ${ }^{163}$

The Court supported its above judgment with the following arguments which allow the extract of interesting conclusions also within the context of application of the CISG:

(i) that the specific Bullet-Proof Material was used by the army forces and the police in more than 50 countries without any problems; ${ }^{164}$

(ii) that in the financial tender submitted to the State Weapon Co. on 14.2.2000 at the pre-contractual stage, the Seller pointed out that the Bullet-Proof Material was a new product in the market and did not exist for enough time in order to have real experience data; ${ }^{165}$ accordingly, on the Court's opinion, the Buyer had not violated the principles of good faith and transactional morals, but, on the contrary, it complied with its obligations to enlighten and protect the State Weapon Co. and the Buyer at the pre-contractual stage;

(iii) that even if it was the case that the Bullet-Proof Material "behaved" differently according to the design and type of the bullet-proof vest, again the obligation to enlighten and protect the State Weapon Co. and the Buyer would not reach this point, i.e. that the Seller was obliged to inform the State Weapon Co. and the Buyer as to this differentiation, since the State Weapon Co. and the Buyer were obliged to be informed and could had been informed such differentiation following their own investigation; this was due to the fact that they had extended experience and know-how and also had cooperated in the past (1994) with the Seller and had purchased before its bullet-proof material thus being aware of the exact specifications of the Bullet-Proof Material.

As said the above judgment of the Court on the relevant matters of substance can also lead to the result that article 40 CISG would not apply under the specific facts; ${ }^{166}$ besides it can be suggested that room would be left for the application of article $35, \S 3$ CISG. ${ }^{167}$

\footnotetext{
163. See infra 49 (viii).

164. See infra $₫ 49$ (vi).

165. See supra $₫ 2$.

166. See supra 9 ๆ 27, 39(ii).

167. See supra $₫ \uparrow 26,39$ (iii).
} 
(5) Buyer's Action: Buyer's Claim for Non-Pecuniary Damage-Court's Judgment on Legal Issues

40. As regards the Seller's claim for monetary compensation due to moral distress, the court, in our opinion, rightly judged that the action was groundless in law to the extent that it was based on the CISG provisions. In order to support this judgment the Court invoked the following arguments: (i) that the non-pecuniary damage is not recovered under the CISG; and (ii) that based on the theory of foreseeability applied in the CISG the Seller could not have foreseen (subjective foreseeability) neither was it obliged to have foreseen (objective foreseeability) the non-pecuniary damage invoked by the Buyer as a possible consequence of the contractual breach at the time the contract was concluded. ${ }^{168}$

(6) Buyer's Action: Seller's Objection for Statutory Limitation (Prescription)-The Bullet-Proof Material as an Instalment Contract: Commencement of Prescription Period_Court's Judgment on Legal Issues and Methods of Interpretation

41. The Seller raised an objection for statutory limitation claiming that since it delivered to the Buyer the agreed instalments ("shipments") of the Bullet-Proof Material from January 2002 to July 2002 (see above par. 6), the Buyer informed it (the Seller) of the lack of conformity with the terms of the Bullet-Proof Material Sale Contract due to the penetration of the sold BulletProof Material, by the letter dated 9.10 .2002 of its parent company State Weapon Co. ${ }^{169}$ and filed the relevant action on 21.12.2006. Therefore, the claims of the Buyer for lack of conformity of the Bullet-Proof Material with the terms of the Bullet-Proof Material Sale Contract were subjected to statutory limitation (prescription). The court judged that the above objection of the Seller for statutory limitation was legally grounded based on articles 247, 277, 554 and 555 Greek Civil Code (the "GCC") as in force at that time (in conjunction with CISG 39). ${ }^{170}$ The above application of Greek domestic

168. Judgment 4505/2009 at 49-50. See also supra $\uparrow 16$.

169. See supra $₫ 7$.

170. Prior to the amendments imposed by Law 3043/2002, the following applied: in relation to the sale of movable goods any action for the reversion of the sale or price reduction or compensation for real defect or absence of agreed quality was prescribed within six months, GCC art. 554; this prescription commenced as of delivery of the movable good to the buyer, GCC art. 555; however, the seller could not 
provisions was correct since, as the court judged, in connection with statutory limitation (prescription), there is a gap in the CISG which cannot be regulated on the basis of a general principle thereof and for that reason, according to the Greek Private International law (forum), the Greek law was the applicable law, since it was the law selected by the parties in the Bullet-Proof Material Sale Contract. ${ }^{171}$

42. In order to rebut the above objection for statutory limitation raised by the Seller, the Buyer claimed inter alia (by means of a reasoned refusal of the objection of the Seller) the following:

(i) that, by virtue of the Bullet-Proof Material Sale Contract it was agreed to deliver 155,000 $\mathrm{lm}$ of Bullet-Proof Material in instalments ("shipments") which, by the nature of the Bullet-Proof Material Sale Contract, constituted provisions of one and the same thing; and

(ii) that, due to the fact that the Seller did not comply with the terms of the Bullet-Proof Material Sale Contract, the Buyer did not take delivery of the last quantity of $29,871 \mathrm{~lm}$ of Bullet-Proof Material, thus resulting, due to the fact that the Buyer did not take delivery of the last quantity of Bullet-Proof Material, that the period for the statutory limitation (prescription) of this claim (for lack of conformity) had not commenced and thus it could not be statutory limited (prescribed). ${ }^{172}$

From the content of the above argument it is apparent that the Buyer substantially claimed that the Bullet-Proof Material Sale Contract was not a contract for self-existent instalments of goods (i.e. an instalment contract), ${ }^{173}$ but a contract for partial deliveries of goods which were not self-existent amongst them, i.e. a contract where one and the same thing was delivered in parts; ${ }^{174}$ on this basis the Buyer claimed that the statutory limitation

plead the six month prescription, GCC art. 554, if it intentionally concealed the defect or the absence of the agreed quality. GCC art. 557.

171. See CISG art. 7, § 2 and arts. 3, § 1 and 10(d) of Law 1792/1998 which implemented the Rome Convention in Greece. $C f$. Monomeles Protodekeo [Single Member First Instance Court of Larissa] Greece, 2005, available at $\mathrm{http} / / / \mathrm{cisgw} 3$.law.pace.edu/cases/050165gr.html;SCHWENZER, supra note 35, at 95 ("limitation of actions are not governed by the CISG but are governed by domestic law or the UN Limitation Convention"). Greece has not implemented the United Nations Convention on the Limitation Period in the International Sale of Goods (1974). Please note that same solution would apply under the current Greek private international law rules included in Regulation 593/2008 on the "Law Applicable to Contractual Obligations."

172. See supra note 170.

173. See CISG art. 73.

174. See supra $\lceil 20$. If this was the case (i.e. the $155,000 \mathrm{~lm}$ of Bullet-Proof Material were considered one thing delivered in parts as opposed to independent and self-existent instalments) then the Buyer could 
(prescription) does not commence if the delivery of the total quantity of $155,000 \mathrm{~lm}$ of Bullet-Proof Material (thus including the 11th shipment of the $29,871 \mathrm{~lm}$ ) sold had not been effected. As mentioned ${ }^{175}$ the Court, correctly in our opinion, judged that the Bullet-Proof Material Sale Contract was an instalment contract, since the instalments ("shipments") of the Bullet-Proof Material were self-existent as compared among them. Furthermore, following the findings of Greek legal doctrine, the Court correctly judged that the time set for the statutory limitation under article 554 GCC commenced, not from the delivery of the goods to the Buyer (as provided by art. 555 GCC), ${ }^{176}$ but from the date of notification (pursuant to article 39, § 1 CISG) of the Buyer to the Seller concerning the lack of conformity. ${ }^{177}$ In order to support this interpretation, the Court innovated quoting the following correct, in terms of teleological nature, argument: a different interpretational approach, consisting in the non-commencement of the statutory limitation, when the goods have not been delivered, in case that the Buyer declares an instalment contract avoided as regards a specific instalment, due to the non-performance of the Seller's obligations that derive from the sale contract, according to the provision of article $73, \S 1$ CISG, would lead to a situation where the Buyer's claims against the Seller could not be prescribed, which cannot be tolerated by any legal regime. ${ }^{178}$ That is in the latter case, the Court, practically considered that

still, under art. 51, § 1 CISG, avoid the Bullet-Proof Material Sale Contract with respect to the nonconforming part (provided of course that the non-conformity constituted fundamental breach) since the latter provision permits the Buyer to sever the portion of a contract relating to a missing or non-conforming part of a single delivery: $c f$. Flechtner, supra note 73 , at 89 .

175. See supra $₫ 20$.

176. See supra note 170.

177. Judgment $4505 / 2009$ at 12,53 ("“W]hen the Greek Law is applicable and more specifically the provision of Article 554 of the Civil Code prior to its amendment with Law 3043/2002, which provided that the statutory limitation for movable goods had a term of six months and therefore it was shorter than the two-year [notice] period provided for by Article 39(2) of the CISG, it must be accepted that for sales falling within the sphere of application of the CISG, the period of six months statutory limitation provided for by Article 554 of the Civil Code commences not from the handing over of the goods to the buyer, but as of the notification of the buyer to the seller provided for by Article 39(1) of the CISG."). Such interpretation was necessary in order to remedy issues created due to the fact that the prescription period set out in article 554 GCC (6 months) was shorter than the period set out in article 39, § 2 CISG (2 years). See Monomeles Protodekeo [Single Member First Instance Court of Larissa] Greece; Valtoudis, supra note 152, at 341; Athanasios Pouliades, The Obligations of Seller and Buyer Under the Vienna Convention for the International Sale of Goods-General Characteristics, Issues on the Application of the Vienna Convention for the International Sale of Goods 89 (F. Doris \& A. Chelidonis eds., 2004). Following the amendment of the Greek Civil Code by Law 3043/2002, any action of the buyer for real defect or absence of agreed quality in the sale of movable goods is prescribed within two years, see GCC art. 554; this prescription commences as of delivery of the goods to the buyer, see GCC art. 555.

178. Judgment $4505 / 2009$ at 53 . 
with the opposite interpretation it would be led to a socially intolerable result (argumentum ad absurdum). ${ }^{179}$

Based on the above it is apparent that the Court, in order to provide an acceptable solution to the issue as to the time of commencement of the prescription (domestic law issue) of the Buyer's remedies in an instalment contract governed by the CISG (issue governed by the CISG) it made reference to a method of interpretation (teleological) used under Greek law in order to interpret domestic provisions. This methodological approach raises, however, the issue whether methods of interpretation used in domestic legal systems (literal, historical, systematic and teleological interpretation) can also be used to interpret the provisions of the CISG. We share the opinion that the use of these interpretative methods is acceptable ${ }^{180}$ since these are methods shared within the common legal tradition of the Contracting States and are not exclusively attached to one or more domestic laws; however, such use will only be acceptable within the context of the Convention without reference to domestic legal doctrine and case law. ${ }^{181}$ On this basis it is suggested that when the provision(s) of the CISG is (are) interpreted one could adopt the following model of interpretation: usually first, look to the actual text of the Convention in the original languages (i.e. literal interpretation), make reference to the preparatory discussions and the secretariat commentary (i.e. historical interpretation), find solutions arising from the "location" of a specific provision in the CISG and its interrelationship to other CISG provisions or general principles (i.e. systematic interpretation) and/or find solutions on the basis of the Convention's general principles ${ }^{182}$ with particular emphasis on the need to promote uniformity and to observe good faith in international trade ${ }^{183}$ (i.e. teleological interpretation). On this basis it would be preferable if the Court had based the adopted interpretation-suggested solution on article $7, \S 1$ CISG i.e. that non-commencement of prescription in an instalment contract

179. For the concept of the argumentum ad absurdum within the context of the teleological interpretation, see P. Papanikolaou, Methodology of Private LaW and Inter pretation of Legal TRANSACTIONS 179 (2000).

180. See Georgios Nikolaides, The Vienna Convention (law 2532/1997) on the International Sale of Goods (CISG): its Creation and the Compromises that it Expresses, Critical Review of Legal Doctrine and Practice 130 (1999). Few authors are skeptical on the use of the teleological method of interpretation within the CISG context. See P. Papanikolau, K. Roussos, K. Christodoulou \& A. Karabatzos, The New Law of the Seller's Liability 267-68 (Ant. N. Sakkoulas ed., 2003). A. Chelidonis, Vienna Convention on the International Sale of Goods-Setting the Limits of the Sphere of Application and Theory of Legal Transactions, CHRON. PRIVATE L. 871, 875 (2001).

181. CISG art. 7, § 1 .

182. CISG art. $7, \S 2$.

183. CISG art. $7, \S 1$. 
prior to delivery of all instalments would be an interpretation which would lead to a socially intolerable result and therefore to non-compliance with good faith in international trade (which in our opinion would obviously be the case).

43. In order to rebut the above objection for statutory limitation (prescription) $)^{184}$ the Buyer further claimed that the Seller, being aware due to its extensive experience and know-how at the time the risk was transferred to it, that the Bullet-Proof Material failed in its antiballistic qualities with respect to the type of the bulletproof vest for which it (the Bullet-Proof Material) would be used, although it (the Seller) was obliged to notify to the Buyer the lack of the quality agreed upon, it deliberately concealed it in order to undertake the procurement, ${ }^{185}$ and that, if the Buyer was aware that the BulletProof Material of the Seller responds differently according to the intended use and it is possible that it is rendered inappropriate, it (the Buyer) would never have proceeded with the conclusion of the Bullet-Proof Material Sale Contract. The Court judged that: (i) this allegation of the Buyer constituted a counter-objection against the statutory limitation (prescription) objection ${ }^{186}$ and it was legally grounded based on article $557 \mathrm{GCC},{ }^{187}$ since in this case the period for statutory limitation is set to twenty years ${ }^{188}$ instead of six months; ${ }^{189}$ and (ii) article 557 GCC applied as part of the law to which the Private International Law of Greece (forum) refers to, since the CISG does not include a specific provision or general principle that regulates the statutory limitation. ${ }^{190}$ As mentioned before it is questionable whether the Buyer could had raised a similar argument within the context of article 40 CISG in order to avoid the adverse circumstances from articles 38 and 39 CISG. ${ }^{191}$

184. See supra $\mathbf{\Phi} \mid 41,42$.

185. See supra $\llbracket 2$.

186. See supra $\uparrow \uparrow 41,42$.

187. See supra note 170.

188. GCC art. 249. The term of prescription for claims stemming from contractual rights is, as a general rule, twenty years, See GCC art. 249. Exceptionally (e.g., in the case of commercial claims or claims for salary or fees or interest or rent, etc.), it is five years or, when special provision is made for this, different, that is, even shorter GCC art. 554. See supra note 170; Stathopoulos, supra note 126, at 207-08.

189. GCC art. 554. See supra $\uparrow$ 甲 41,42 , note 170.

190. See CISG art. 7, § 2 and arts. 3, § 1 and 10(d) of Law 1792/1998 which implemented the Rome Convention in Greece. Please note that same solution would apply under the current Greek private international law rules included in Regulation 593/2008 on the "Law Applicable to Contractual Obligations"; see also supra 941 , note 170.

191. See supra $\llbracket 27$. 
44. Finally, the Seller justifiably denied the above counter-objection of the Buyer, ${ }^{192}$ claiming that its liability as the producer of the raw material (i.e. the Bullet-Proof Material) is exhausted in the specifications possessed by the Bullet-Proof Material, which were successfully tested and confirmed not only before the Seller's selection as supplier, ${ }^{193}$ but also during the new ballistic tests conducted on 30.10.2002 and 01.11.2002. ${ }^{194}$

(7) Buyer's Action: Seller's Objection for Liable Non-Mitigation by the Buyer of Its Loss (Article 77 CISG)—Court's Judgment on Legal Issues

45. The Seller claimed that the Buyer was liable for not mitigating its loss, since it could have achieved a higher security (protection) cap for the Bullet-Proof Vests through the addition of another polyurethane material (weighing $24 \mathrm{~g}$ ) which it could have acquired from the Seller, of a value of $€ 0,33$ per Bullet-Proof Vest, which corresponded, for the improvement of the 6,900 Bullet-Proof Vests to the total amount of $€ 2,277$, against the amount of $€ 418,509.29$ which the Buyer born in order to repair the Bullet-Proof Vests. ${ }^{195}$ The Court judged that this allegation of the Seller constituted an objection ("enstasi") and was legally grounded based on article 77 CISG (i.e. duty of the damaged party to mitigate its loss). ${ }^{196}$ The fact that the Court characterised this allegation as an objection ("enstasi") means that the Court accepted the following: (i) a defence that the party who seeks damages has violated its duty to mitigate damages under article 77 CISG has to be raised by the party against whom damages are sought and is not to be ex officio examined by a court: ${ }^{197}$ and (ii) the party against whom damages are sought has the burden

192. See supra 94.

193. See supra $₫ 2$.

194. See supra $₫ 8$.

195. See supra $\uparrow \uparrow 11,30,32$.

196. Judgment $4505 / 2009$ at $54-55$. Such allegation definitely falls within the ambit of article 77 CISG since it is accepted that under this provision a buyer of non-conforming goods may be under a duty to have them repaired in order to prevent them from worsening or to avoid consequential losses. See Ingeborg Schwenzer \& Simon Manner, The Pot Calling the Kettle Black: The Impact of the Non-Breaching Party's (Non-) Behaviour on its CISG-Remedies, Sharing International Commercial Law aCross National Boundaries: Festschrift for Albert H. Kritzer on the Occasion of his Eightieth Birthday 470, 481 (C.B. Andersen \& U.G. Schroeter eds., 2008). Peter Riznik, Article 77 CISG: Reasonableness of the Measures Undertaken to Mitigate the Loss, PaCE L. Sch. Inst. InT'L Com. L. $\S$ 4.2.2(a), available at http://www.cisgw3.law.pace.edu/cisg/biblio/riznik.html.

197. This is a controversial issue. See SCHWENZER, supra note 35, at 1048. On the opinion that this defence is examined by a court ex officio, see Stoll \& Gruber, Commentary on the UN Convention ON THE InTERNATIONAL SALE OF GoOdS (CISG) 793 (Peter Schlechtriem \& Ingeborg Schwenzer eds., 2d ed. 2005) ("Article 77 not only grants the party liable for damages a right to withhold payment, but 
to prove that the party who seeks damages has violated its duty to mitigate loss under article 77 CISG. ${ }^{198}$

(8) Buyer's Action: Buyer's Claim for the Payment of Price Under a Sales Contract Concluded for Parts of the Bullet-Proof Material That Would Be Left over from the Process (Waste)—Court's Judgment on Legal Issues and Substance

46. The Court did not accept that a contract had been concluded by virtue of which the Seller was obliged to purchase from the Buyer the parts of the Bullet-Proof Material that would be left over from the process (waste) for a price of 5 Deutsch Mark ("DM") or $€ 2.56$ per kg and thus accepted that the Seller had no contractual obligation to take delivery of the quantity of the Bullet-Proof Material that was left over after the process conducted by the Buyer and therefore he was not obliged to pay to the Buyer the amount of $€ 8,151.08$ as the purchase price of the above quantity. The Buyer based its request on the fact that the offer of the Seller to the Buyer dated 14.2.2000 included a relevant clause with which the Seller accepted to purchase the parts of the Bullet-Proof Material that would be left over from the process (waste) for a price of $5 \mathrm{DM}$ per $\mathrm{kg}$. The Court however, rejected the Buyer's request, being based on clause 9.2 of the Bullet-Proof Material Sale Contract where it was provided that this agreement supersedes any other relevant document. ${ }^{199}$

establishes a defense that may extinguish the claim and must be ex officio considered."); Bundesgerichtshof [Federal Supreme Court] Germany, 24 Mar. 1999, available at http://cisgw3.law.pace.edu/cases/ 990324g1.html ("CISG article 77 establishes a defense that may exclude a claim and must be considered sua sponte."); Arbitral Award of the International Chamber of Commerce (ICC) No. 9187/1999 (1999) ("The party claiming damages has an obligation to mitigate the loss (Art. 77 CISG), otherwise it is deprived of its right to damages. Whether the claiming party has complied with this duty has to be considered by the Arbitral Tribunal ex officio, whereby the burden of proof for the fact that a loss could have been avoided lies with the party owing damages."). On the opinion that this defence has to be raised by the party against whom damages is sought, see Oberster Gerichtshof [Supreme Court] Austria, 6 Feb. 1996, available at http://cisgw3.law.pace.edu/cases/960206a3.html ("The claim of the breach of the duty to mitigate damages is an exception leading to the loss of the claim for damages. It requires the [sellers] to put forward detailed facts and the supporting evidence showing why the [buyer] has breached its duty to mitigate damages, the possibilities of alternative conduct and which part of the damages would have been prevented by this alternative conduct.").

198. See SCHWEnZER, supra note 35, at 1048 ("The burden of proof for the claim that the promisee has violated his duty to mitigate damages under Article 77 rests on the promisor. On the other hand, the promisee bears the burden of proof insofar as he claims damages under Article 74 for measures taken to avoid or mitigate loss"); Oberster Gerichtshof [Supreme Court] Austria, 6 Feb. 1996, available at http://cisgw3.law.pace.edu/cases/960206a3.html; cf. Arbitral Award of the International Chamber of Commerce (ICC) No. 9187/1999 (1999).

199. See supra $₫ 4$. 
(9) Buyer's Action: Buyer's Claim for the Seller's Portion in the Ballistic Tests Expenses

47. The Court adjudicated the Buyer the amount of $€ 7,670.87$ which corresponded to the Seller's portion in the expenses of the ballistic tests conducted in the ballistic center of the University "G" in the U.K. ${ }^{200}$

\section{Seller's Action: Objection by the Buyer for Lack of CONFORMity-Buyer's Action: Buyer's Claim For \\ Compensation-Court's Judgment on the Substance of the Buyer's ObJection and Compensation Claim}

A. Criteria for the Substantiation of the Judgment That the Bullet-Proof Material Was in Conformity with the Bullet-Proof Material Sale Contract

48. By judging that there was no lack of conformity of the Bullet-Proof Material with the Bullet-Proof Material Sale Contract in the sense set out in the CISG the Court:

(i) opined on the substantial grounds of the Buyer's claim for compensation $(€ 612,423.655)$ for the damage that the latter suffered due to the request of the Ministry for repair of the Bullet-Proof Vests and the subsequent replacement of the Bullet-Proof Material with aramidic fibres (Kevlar); ${ }^{201}$ and

(ii) rejected the relevant objection for the lack of conformity of the Bullet-Proof Material with the requirements of the Bullet-Proof Material Sale Contract that the Buyer raised in the context of the Seller's action. ${ }^{202}$

The Court grounded its above judgment on the determination that at the time the risk was transferred ${ }^{203}$ the Seller complied with the Bullet-Proof Material Sales Contract by delivering to the Buyer the agreed Bullet-Proof Material, with a width of $160 \mathrm{~cm}$ per quantity, quality and kind in accordance with the terms of the Bullet-Proof Material Sale Contract, without having actual defects and equipped with the reasonably expected qualities that the Seller

200. See supra $₫ 2$.

201. See supra 9 \ $32,34$.

202. See supra $\uparrow 17$.

203. See supra $\llbracket 28$. 
presented to the Buyer ${ }^{204}$ in the filing of its bid dated 14.2.2000 to the State Weapon Co. (holding company of the Buyer) and which were confirmed during the ballistic tests conducted in the University "G" in the U.K. for the selection of the Buyer's supplier, ${ }^{205}$ in which tests, after inspecting the conduct of the unprocessed Bullet-Proof Material and not its application in a specific model of bulletproof vest, it was selected as the most appropriate one among other materials.

49. The Court supported the above, correct in our opinion, judgment in an exemplary manner with a number of arguments ${ }^{206}$ which derived from: (i) the negotiations between the parties ${ }^{207}$ (ii) the interpretation of the terms of the Bullet-Proof Material Sale Contract; ${ }^{208}$ and (iii) the total of the circumstances in question including non-contractual ones (e.g., existence of compliance certificates, test results, acceptance of instalments already delivered). ${ }^{209}$ These arguments substantiated in the CISG context, the conformity of the Bullet-Proof Material sold with the requirements and terms

204. Cf. CISG arts. $35,36,66,67,68,69$.

205. See supra $\uparrow 2$.

206. These arguments appear to be legally grounded on principles of law. Judgment 4505/2009 at 14-15 ("In particular, the primary contractual obligation of the seller is to hand over to the buyer goods which are of the quantity, quality and description and conform to the requirements of the contract (CISG Article 35(1). In parallel, the subjective (CISG Article 35(2)(b) and (c)) and objective criteria, respectively, are set out (CISG Article 35(2)(a) and (d)), which, also within the framework of the Civil Code are used for the conceptive determination of the real defects, while it is still possible to agree upon qualities, whose possible lack would not have been [otherwise] considered as a lack of conformity of the goods to the requirements of the contract. In other words, the seller has a main contractual obligation to hand over the goods free of defects, actual or legal, and equipped with the reasonably expected (and not compulsory "agreed upon") qualities (Multi-Member First Instance Court of Thessalonica 22513/2003, as above). Respectively, a form of breach of the contractual obligations of the seller is also the handing over to the buyer of defective goods or, although not defective, of such a kind that they do not conform to the requirements of the contract as, e.g., when the goods handed over do not have the qualities agreed upon. Nevertheless, the parties, pursuant to CISG Article 6, may agree upon when the goods do conform to the requirements of the contract, and the content of the said agreement shall be determined by the interpretation of the contract and the declarations of the parties (CISG Article 8). If no such agreement exists, the extent for the conformity may derive from any usages to which the parties have agreed and by any practices which they have established between themselves (CISG Article 9(1), otherwise, by the usages of international trade which the parties knew or ought to have known and which the parties are presumed to have applied to their mutual sales contract. If none of the above applies, then the conformity of the goods to the contract shall be judged based on the above criteria set out in the provisions of CISG Article 35(2) (D. Flambouras "International Sales" in Ch. Pamboukis (edit.), International Transactions Law, Athens, Law Library (to be published) paragraph 228, with reference to a judgment law of a foreign court").

207. See CISG art. 8; see also supra 9 ๆ 2,39, and see infra part v.

208. See CISG arts. 6, 8; see also supra 9 , and see infra parts iv, v, vi.

209. See CISG art. 8, § 2; see also supra 9 , and see also infra parts i, ii, iii, iv. 
of the Bullet-Proof Material Sale Contract ${ }^{210}$ and can be summarised as follows:

(i) Instalments ("shipments") no. 7, 9 and 10 of the Bullet-Proof Material which were accompanied by compliance (quality) certificates, ${ }^{211}$ were received by the Buyer and successfully passed the quantitative and qualitative controls by the competent departments of purchases and quality control of the Buyer, ${ }^{212}$ without the Buyer rejecting any quantity of Bullet-Proof Material due to an actual defect or absence of the reasonably expected qualities or because there was a qualitative deviation from the agreed specifications, since the Bullet-Proof Material was indeed of first class quality and fulfilled by $100 \%$ the specifications and its characteristics. ${ }^{213}$

(ii) The exceptional quality of the Bullet-Proof Material was additionally evidenced by the ballistic tests conducted on 30.10.2002 at the Greek Ballistic Station ${ }^{214}$ in the context of which approximately 80 shots

210. CISG art. 35, § 1, Judgment $4505 / 2009$ at $93-98$.

211. The "compliance certificates" constituted documents that the Seller was obliged, under the Bullet-Proof Material Sale Contract (clause 2.6), to hand over, in the sense of article 30 CISG. See CoRINNE Widmer, Commentary on the UN CONVENTION ON THE InTERnATIONAL SALE OF Goods (CISG) 1015 (Peter Schlechtriem \& Ingeborg Schwenzer eds., 3d ed. 2010) ("The answer to the question whether the seller has to hand over documents, and, if so, which documents, is to be found in the contract, any usage applicable in accordance with Article 9, and the principle of good faith.").

212. See supra $\uparrow 6$.

213. In consistence with the above under (i) argument, the Court accepted that each instalment ("shipment") which was delivered to the Buyer, was accompanied by the respective sale invoices and compliance certificates with the specifications of the Bullet-Proof Material for the quantities ordered by the Buyer. See Judgment 4505/2009 at 76. Furthermore, as concluded by the Court's assumptions quoted at the same point, the compliance certificates: (i) certified that the Bullet-Proof Material supplied by the Seller to the Buyer fulfilled the applicable manufacture specifications for product level which was inspected in accordance with the internal control procedures used by the Seller; and (ii) made clear reference to the fact that the Buyer should inspect the product level (of the Bullet-Proof Material) for the actual application (i.e. its use for the manufacture of Bullet-Proof Vests) and that the Buyer was not released from its obligation to conduct the regular inspection of the products (i.e. the Bullet-Proof Material) it took delivery of. $I d$. From the above content of the compliance certificates which accompanied the quantities (instalments) of BulletProof Material delivered to the Buyer but also from the affidavit of an officer of the Seller dated 5.11.2007, the Court concluded that the Seller, in its capacity as the raw material supplier guaranteed only that the raw material (i.e. the Bullet-Proof Material) will conform with the relevant specifications (included in the Bullet-Proof Material Sale Contract), See supra $₫ 4$, and no other guarantees would be granted; it was, therefore, a responsibility of the manufacturer of the Bullet-Proof Vests (i.e. the Buyer) to select the materials of the vests, to design and properly manufacture the Bullet-Proof Vests, so as to achieve the required protection level (a level provided for in the Bullet-Proof Vests Supply Contract), see supra $\uparrow 3$, and see infra parts iv, v, vi. See Judgment 4505/2009 at 76.

214. See supra $₫ 7$. 
were taken on the same Bullet-Proof Material and in particular in samples randomly selected from the batch No. 110097 of the BulletProof Material and mainly from the box numbered 200203244, which was used to manufacture the Bullet-Proof Vest that, during the ballistic tests on 20.9.2002, had been punctured at the fifth shot; on the above tests (conducted on 30.10.2002) the Bullet-Proof Material did not exhibit any unusual conduct, so as to be characterized as suspicious for the failure. ${ }^{215}$ Based on these findings the Failure Analysis dated 10.3.2003 concluded that from the results of the ballistic tests, the failure of the Bullet-Proof Vest was not attributed to systematic failure of the used Bullet-Proof Material. ${ }^{216}$

(iii) As regards the puncture of the Bullet-Proof Vest on 20.9.2002 ${ }^{217}$ and the equation model of the bullet-proof vest under examination on 1.11.2002 $2^{218}$ the Court noted the following: (1) both ballistic tests were conducted at the Greek Ballistic Station, ${ }^{219}$ which however was not certified by the international standards; (2) ammunition was used which was not provided for in Annex B of the Bullet-Proof Vests Supply Contract; ${ }^{220}$ (3) during the third test, larger velocities were measured in comparison with the specifications requirements; (4) during the second test, the five shots were taken in an imaginary line on the equation model of the type of bulletproof vest under examination, instead of being conducted in a triangular layout, with the observance of specific distances of the points to which the Bullet-Proof Material is shot, in accordance with the safety standard NIJ 0101.03. In view of the above, the Court judged that the results of the ballistic tests could not be considered safe and creditworthy.

(iv) Based on the ballistic tests on the design equation model [see above subpar. (iii)], the Failure Analysis ${ }^{221}$ concluded that the puncture was a strong indication of malfunction of the Bullet-Proof Material in the specific design (i.e. of the Bullet-Proof Vest). Again the Court accepted that the Seller bore no contractual liability for the conduct of the end product, i.e. the Bullet-Proof Vest. The Seller was not a 
contracting party to the Bullet-Proof Vests Supply Contract ${ }^{222}$ and therefore it (the Seller) had no liability towards the Ministry for the domestic manufacturing and the end product (Bullet-Proof Vest). ${ }^{223}$

(v) Upon execution of the Bullet-Proof Material Sale Contract ${ }^{224}$ the Seller undertook the obligation to deliver to the Buyer $155.000 \mathrm{~lm}$ of raw (unprocessed) Bullet-Proof Material of $160 \mathrm{~cm}$ width. In the Bullet-Proof Material Sale Contract, there was no reference in the form of reference, incorporation or Annex, neither to the BulletProof Vest Supply Contract ${ }^{225}$ or the Annexes thereof not to the invitation dated 24.1.2000 of the State Weapon Co. to the Seller for the submission of a financial offer as regards antiballistic material for the manufacture of a bulletproof vest, ${ }^{226}$ nor to any other contractual text or document. ${ }^{227}$ Furthermore, in accordance with cl.

\section{See supra $\llbracket 3$.}

223. The argument set out in sub-paragraph (iv) evidences that the Court interpreted the Bullet-Proof Material Sale Contract (without though making detailed reference to the criteria of art. 8 CISG), see supra note 206, and see infra note 227, and found that no clause was included (or otherwise incorporated), see infra part $\mathrm{v}$, under which the Seller took any liability for the conduct of the end product (i.e. the BulletProof Vest). See CISG arts. 6, 8; see also supra note 213. On this basis to the extent that the Bullet-Proof Material complied with the specifications of the Bullet-Proof Material Sale Contract it was in conformity with the latter irrespectively of the "conduct" of the Bullet-Proof Vest to be manufactured from the BulletProof Material. See CISG art. 35, § 1. In any event the "conduct" of the Bullet-Proof Vest was to be determined by reference to the Bullet-Proof Vests Supply Contract, see supra $\uparrow 3$, in which, as the Court correctly stressed, the Seller was not a contracting party and to which the Bullet-Proof Material Sale Contract did not make reference in the form of reference, incorporation, Annexes or otherwise. See infra part v.

224. See supra 94.

225. See supra 93

226. See supra $\uparrow 2$.

227. See supra part (iv). The arguments set out in sub-paragraphs (iv) and (v) evidence that the Court considered the conformity of the Bullet-Proof Material to the Bullet-Proof Material Sale Contract by virtue of article 35, § 1 CISG since the Bullet-Proof Material Sale Contract contained sufficient details of the requirements to be satisfied by the Bullet-Proof Material for the purposes of this last provision. The Court did not seem to have applied any of the criteria set out in article 35, §2 CISG since the latter only applies in so far as the contract does not contain any, or contains only insufficient, details of the requirements to be satisfied by the goods for the purposes of article 35, § 1 CISG. See SCHWENZER, supra note 35, at 575; see also Cesare Massimo Bianca, Commentary on the International Sales LaW: The 1980 Vienna Sales Convention Giuffré, Milan 272 (C.M. Bianca \& M.J. Bonell ed., 1987) (“[T] he criteria of Article 35 are to be applied only in the absence of an express or implied contractual provision. Thus, one must first seek the proper content of the seller's obligations through interpretation of the contract (see Article 8) [...] these criteria cannot be applied if there is a minimum of contractual indications about the goods to be provided by the seller."]. Harry M. Flechtner, Funky Mussels, a Stolen Car, and Decrepit Used Shoes: NonConforming Goods and Notice thereof under the CISG, 26 B.U. INT'L L.J. 1, 4 (2008); Kristian Maley, The Limits to the Conformity of Goods in the UN CISG, 12 INT'L TRADE \& BUS. L. REV. 82, 104 (2009) ("As the seller's obligations in relation to the goods are defined according to the parties' agreement, the presence 
9.2 of the Bullet-Proof Material Sale Contract, the Seller and the Buyer agreed that this contract supersedes any other relevant document. ${ }^{228}$ Consequently, the terms referred to in the Bullet-Proof Material Sales Contract formed the contractual relations between the Seller and the Buyer, excluding the possibility of applying any other contractual term. ${ }^{29}$

(vi) The Seller, in its capacity as supplier of raw material, had guaranteed under clause 7.3 of the Bullet-Proof Material Sale Contract that the Bullet-Proof Material would be free from any apparent or hidden defect (i.e. it provided a guarantee for its quality) for a period of one (1) year commencing from the date of delivery; ${ }^{230}$ nevertheless, no corresponding clause was included in the Bullet-Proof Material Sale Contract providing for the granting of warranty by the Seller for the proper design and manufacturing of the bulletproof vests. Consequently, the Seller could not bear any responsibility for the storage conditions, the cutting manner and the placement manner of the Bullet-Proof Material in the bullet-proof vest by the occasional manufacturer of bullet-proof vests. ${ }^{231}$ Indeed, despite the fact that the bulletproof vests that were manufactured by the Bullet-Proof

of defects is assessed subjectively."). By means of commentary we note that the Court should had made express reference to the criteria of article 8 CISG, Judgment 4505/2009 (solely referred to article 8 CISG with no further analysis), in order to determine the requirements of the Bullet-Proof Material Sale Contract and the primary test (which was in principle examined by the Court) would be what characteristics of the goods are laid down in the contract by means of quantitative and qualitative description. See SCHWENZER, supra note 35 , at 571 . BIANCA, supra note 227 , at 272 ; Henschel, supra note 114 , at $\S 4.1$ ("“ . . ] the interpretation of what requirements can be made of the goods ... is decided on the basis of an interpretation of the agreement between the parties, so that Article 8 and 9 are actively considered"); Maley, supra note 227, at 108-09. Thomas Neumann, Features of Article 35 in the Vienna Convention: Equivalence, Burden of Proof and Awareness, 11 Vindobona J. Com. L. \& ARB. (VJ) 81, §§ 4, 8 (2007) ("The result of using art. 8 in determining the content of the agreement is that both express and implied statements constitute duties of the Seller. Also implied statements that the Seller could not be unaware of or that a reasonable Seller would have understood impose duties with which he must comply.").

228. See supra $₫ 4$.

229. This statement of the Court is clearly based on articles 6 and 8 CISG and article 35 , § 2 CISG (i.e. "Except where the parties have agreed otherwise") excluding thus from the parties' contractual relationship under the circumstances under examination any rights and obligations not expressly set out in the Bullet-Proof Material Sale Contract. See Richard Hyland, Conformity of Goods to the Contract Under the UN Sales Convention and the UCC, Einheitliches Kaufrecht und nationals Obligationenrecht 305, 309 ( Peter Schlechtriem ed., 1987) (“... the Convention expressly permits the disclaimer of implied conformity requirements").

230. See supra $\uparrow 4$. The Court used the word "guaranteed" in the sense that the seller "promised" and not in the sense of an accessory obligation. Judgement 4505/2009.

231. See Judgement 4505/2009 at 78; see also supra note 213. 
Material were used by the army forces and the police in more than 50 countries (thus proving that the Bullet-Proof Material is appropriate for the manufacture of bulletproof vests), in no place in the world does the Seller undertake the responsibility for manufacturing deficiencies or defects of the bulletproof vests, since the manufacturing of bulletproof vests by third manufacturers falls beyond the control of the Seller and consequently its liability is limited only for any defects of the Bullet-Proof Material it supplies (which, as mentioned, behaved exceptionally in all ballistic tests conducted in the context of tests using this material). ${ }^{232} 233$

(vii) Based on the above, ${ }^{234}$ the sole liability for the necessary protection level of the Bullet-Proof Vests required by the Authority (which protection level was provided in the Bullet-Proof Vests Supply Contract) ${ }^{235}$ was borne by:

232. See supra 9 ๆ $2,8,10$.

233. The content of the argument set out in sub-paragraph (vi) shows that the Court interpreted the Bullet-Proof Material Sale Contract and found that no clause was included under which the Seller took any liability for the proper design and manufacturing of the bulletproof vests. See CISG arts. 6, 8. On this basis to the extent that the Bullet-Proof Material complied with the specifications of the Bullet-Proof Material Sale Contract it was in conformity with the latter even if the Bullet-Proof Material "behaved" differently according to the design and type of the bullet-proof best. See CISG art. 35, § 1; see also supra $\uparrow 39$, note 213. Since the Court considered the conformity of the Bullet-Proof Material to the Butter-Proof Material Sale Contract by virtue of article $35, \S 1$ CISG there was no necessity for the application of article $35, \S 2$ CISG. See supra note 227. However, the argument of the Court set out in sub-paragraph (vi) is also useful within the context of article 35, §2(b) CISG which is implicated if the buyer informs the seller, at or before the time of contract conclusion, that it intends to use the goods for a particular purpose. See Flechtner, supra note 227, at 4 (similar arguments related to the knowledge of the Seller that the goods would be used for a particular purpose were raised by the Buyer within the context of its action based on pre-contractual liability); supra 9 39. In particular from the Court's analysis as set out in sub-paragraph (vi) it is evident that, on the Court's opinion, there was no "particular purpose" within the meaning of article $35, \S 2$ (b) CISG regarding the performance of the Bullet-Proof Vests to be manufactured from the Bullet-Proof Material. In order to render the above opinion the Court also relied on the fact that the same was acceptable in the international market for the sale of bullet-proof material (i.e. that in no place in the world the Seller would bear any responsibility for the storage conditions, the cutting manner and the placement manner of the Bullet-Proof Material in the bullet-proof vest by the occasional manufacturer of bullet-proof vests). Furthermore it is accepted by legal doctrine that there may not be any "reliance" for the purposes of article $35, \S 2$ (b) CISG, if the buyer takes part in the selection of the goods, examines the goods before purchase or provides specific specifications. See SCHWENZER, supra note 35, at 582; Neumann, supra note 227, at $\S 9$. It is suggested that the above circumstances applied since the Buyer (and/or the State Weapon Co.) set specifications for the Bullet-Proof Material, took part in its selection and examined it at the pre-contractual stage, see supra 9 ; furthermore the Seller informed the Buyer that "the Bullet-Proof Material was a new product in the market and that it did not exist for enough time in order to have real experience data." See supra 9 ๆ $2,39$.

234. See supra parts iv, v, vi.

235. See supra $₫ 3$. 
(1) the State Weapon Co. since by virtue of the Bullet-Proof Vests Supply Contract ${ }^{236}$ the State Weapon Co. had warranted the proper conduct of the antiballistic materials procured; and

(2) the Buyer since in the Bullet-Proof Vests Manufacturing Contract in which the Buyer was a party it had been provided that the Bullet-Proof Vests Supply Contract constituted an annex and integral part thereof. ${ }^{237}$

(viii) Both penetrations ${ }^{238}$ could not be characterised as a systematic malfunction of the Bullet-Proof Vests, since, both:

(1) in the ballistic tests conducted in the Greek Ballistic Station on 4.9.2003 (where shots were taken on Bullet-Proof Material of the same batch with that of the puncture in the tests dated 20.9.2002 and across the gap that was formed in the junction point of the two front parts of the Bullet-Proof Vest); and

(2) in the ballistic tests conducted by the Seller in its internal shot range and in an international certified lab in the Netherlands, ${ }^{239}$ no penetration was noticed.

In addition, prior to the event (the penetration) on 20.9.2002, 6,900 Bullet-Proof Vests had been delivered in instalments to the Ministry $^{240}$ of which, according to the Bullet-Proof Vests Supply Contract, ${ }^{241}$ one sample had been inspected from each of the ten instalments ("shipments") of Bullet-Proof Material, without any penetration of the Bullet-Proof Vest. Besides, in the Bullet-Proof Vests Supply Contract a "systematic malfunction" is "the case of having this malfunction present on the same antiballistic material within the warranty period and in a percentage exceeding $10 \%$ of the delivered materials"242 which, in the Court's opinion, was not discovered in this case. ${ }^{243}$

237. See supra 95.

238. See supra $₫ 7$.

239. See supra 910.

240. See supra $\uparrow 11$.

241. See supra $\llbracket 3$.

242. $I d$.

243. The content of the arguments set out in sub-paragraphs (i), (ii), (iii) and (viii) shows that in order to interpret the agreement and establish that the Bullet-Proof Material complied with the requirements of the Bullet-Proof Material Sale Contract, see CISG art. 35, § 1, the Court also considered non-contractual circumstances (i.e. the results of other ballistic tests in international certified lab, the fact that ten instalments of Bullet-Proof Material had already been delivered by the Seller and inspected without problems, the fact that there were certificates of quality). See CISG art. 8, § 2; Neumann, supra note 227, 


\section{End Note}

50. As a general conclusion Judgment 4505/2009 can be considered a good example for the application of the CISG providing useful guidance and, in principle, correct interpretation for many provisions. There of course "weaknesses" and room for more clarity and completeness. ${ }^{244}$ It is beyond doubt however the Court's genuine interest and effort to provide solutions "from the CISG" to "issues relating to the CISG" without recourse to Greek domestic provisions and thus "to promote uniformity"; 245 as the Court rightly put it

[T] he interpretation of the CISG by national courts, by virtue of the provision of Article 7(1) CISG, must be made "autonomously," through its uniqueness and originality thereof as a text, i.e., through the system of its provisions and general principles and free of any ethnocentric approaches, "unique" terms of domestic law, and [free] of methods that usually follow for the interpretation of domestic provisions, since otherwise that may result in the application of institutions and provisions of domestic laws and furthermore, in undesired lack of uniformity in its application. ${ }^{246}$

It is a hope (and a wish) that Judges and Arbitrators when applying the CISG will always keep this fundamental rule in mind.

at § 13-14 (suggesting, with reference to relevant case law, that under article $8, \S 2$ CISG a court can take into consideration non-contractual circumstances in order to interpret the sale contract under article $35, \S 1$ CISG].

244. See, e.g., supra $\uparrow 19,20,25,26,28,31,42$, and note 227.

245. See supra $\uparrow$ ๆ $36-38$.

246. See P. Giannopoulos, Principles of Interpretation of the Convention of the UN for the International Sale of Goods, ARMENOPOUlos ANNIVERSARY 83 (2000); Flambouras, supra note 152, at $\S$ 688. Larry DiMatteo, Lucien Dhooge, Stephanie Greene, Virginia Maurer \& Marisa Pagnattaro, The Interpretative Turn in International Sales Law: An Analysis of Fifteen Years of CISG Jurisprudence, 24 Nw. J. INT’L L. \& Bus. 299, 311 (2004); Flechtner, supra note 227, at 5 ("This methodology aims at avoiding ... the tendency to see the international text of the CISG through the lends of preconceptions derived from domestic law."); Joseph Lookofsky, Walking the Article 7(2) Tightrope Between CISG and Domestic Law, 25 J.L. \& Com. 87, 90 (2006); Alexander S. Komarov, Internationality, Uniformity and Observance of Good Faith as Criteria in Interpretation of CISG: Some Remarks on Article 7(1), 25 J.L. \& Сом. 75, 80 (2006). 